\title{
Division of housework within couples in Spain: consequences of educational differences and women's gender-egalitarian beliefs
}

\section{Leandro Iván Canzio}

Swiss National Centre of Competence in Research LIVES, University of Lausanne leandroivan.canzio@unil.ch

\begin{abstract}
Women in Spain are normally equally or more educated than their male partners. However, the gendered division of housework and paid work remains one of the most traditional ones in Europe. Using the 2018 Fertility Survey, I studied how the division of domestic work is affected by women's egalitarian attitudes and partners' relative incomes, and explored the effects of spouses' educational differences, looking at nine possible couple compositions. Two theories of housework division were contrasted: relative resources and doing gender. The results provided little support for the former and wide evidence of the latter. After controlling for relative work and relative wages (among others), only highly educated women do less housework. Nevertheless, it only happens when they are coupled with men that are not low educated. The results suggest that there is more equity if women with upper secondary education also have highly educated partners, but the association is not clear. Simultaneously, men increase their housework contribution if they earn more or the same as women, but not when women are the main earners. No influence of gender-egalitarian attitudes was found. These results contribute to understanding the consequences of educational differences between partners and is the first one to study the effects of gender-egalitarian attitudes on housework division in Spain. Significant limitations must be considered, namely, because of the use of a subjective indicator. The results are best interpreted as pointers for future analyses with time use surveys.
\end{abstract}

Keywords: domestic work; gender equality; unpaid work; doing gender; household specialization; educational differences; gender-egalitarian values; female hypogamy 
Resumen. División del trabajo doméstico en las parejas en España: consecuencias de las diferencias educativas y las creencias igualitarias de género de las mujeres

Las mujeres en España tienen frecuentemente mayor nivel educativo que sus parejas masculinas. Sin embargo, la división de género del trabajo doméstico y del trabajo remunerado sigue siendo una de las más tradicionales de Europa. Mediante la Encuesta de Fecundidad (2018) se han estudiado los efectos de las actitudes igualitarias de las mujeres, los ingresos relativos de los miembros de la pareja, y las diferencias educativas entre ambos (considerando nueve tipos posibles de parejas) en la división del trabajo doméstico. Se contrastaron dos teorías acerca de la división del trabajo doméstico: los recursos relativos y doing gender (hacer género). Los resultados mostraron escaso respaldo hacia la primera, pero una amplia evidencia en favor de la segunda. Controlando por ingresos y trabajo relativo (entre otras), solo las mujeres con estudios superiores realizan menos trabajo doméstico. Sin embargo, esto solo ocurre cuando ellas no están emparejadas con un hombre con bajo nivel educativo. Los hombres aumentan su participación en las tareas domésticas si ganan más o lo mismo que las mujeres, pero no si ellas son las principales proveedoras. No se encontró influencia de las actitudes igualitarias de género. Estos resultados contribuyen a entender las consecuencias de las diferencias educativas entre los miembros de una pareja. Este análisis, además, es el primero que estudia los efectos de las actitudes igualitarias de género en la división del trabajo doméstico en España. Hay limitaciones relevantes debido al uso de un indicador subjetivo. Los resultados deben interpretarse preferiblemente como indicios para futuros análisis con Encuestas de Uso del Tiempo.

Palabras clave: trabajo doméstico; igualdad de género; trabajo no remunerado; doing gender; especialización del hogar; diferencias educativas; valores de igualdad de género; hipogamia femenina

\section{Summary}
1. Introduction
6. Conclusion
2. Background
Appendix
3. Hypotheses
Acknowledgements
4. Data and methods
Bibliographic references

5. Results

\section{Introduction}

Despite the fact that traditionalism has been declining in Spain over the last decades and women are progressively shifting from homemakers to breadwinners, Spanish men are still very reluctant to do housework compared to men in other European countries (Esping-Andersen, 2009).

However, these gender asymmetries do not seem rational or efficient, especially because differences in human capital between partners are inverted. Since the reversal of the gender gap in education occurred in Spain and in many other European countries, educational homogamy became less common while heterogamy shifted from female hypergamy to hypogamy (Esteve et al., 2012; De Hauw et al., 2017). According to Cortina (2007), the proportion of hypo- 
gamous females became higher than that of hypergamous females for the cohort of Spanish women born in the sixties, while homogamy remained as the most usual type of union, particularly among the highly educated. However, even though female hypogamy and homogamy prevail in Spain, women continue to do more housework than men, have lower incomes, attain lower positions, and face one of the highest motherhood penalties in Europe (Amuedo-Dorantes and De la Rica, 2006; Esping-Andersen, 2009; Castaño et al., 2010).

Analyses at the European level show that these new differences in partners' human capital are increasing the bargaining power of women. According to Klesment and Van Bavel (2017) and Van Bavel and Klesment (2017), hypogamous women are more likely than homogamous and hypergamous women to be the main breadwinners and also face lower maternity costs, thus transforming their higher relative education into better labour market outcomes. Nevertheless, it is not clear whether gender differences in educational attainment are reducing asymmetries in housework allocation between women and men (Van Bavel et al., 2018).

Besides improving labour market returns, educational attainment is usually found as a determinant of egalitarian attitudes and beliefs (Bolzendahl and Myers, 2004; Boehnke, 2011), which are related to higher housework performance for men and lower housework performance for women (Aasve et al., 2014). At this point, the following questions motivate this research paper: How do these reversed differences in human capital affect couples' division of paid and unpaid work? Do women perform less domestic work when they "marry down" or when they partner with men that are equally educated? If such a difference exists, is it better explained by relative educational attainment or by the absolute educational level? Is education a "great equalizer" among couples or can these interactions between partners" education increase inequalities? Do gender-egalitarian values affect the division of housework between partners? There are two more latent questions that I try to shed some light on. First, whether differences in housework division are better explained by Becker's human capital theory or by the framework of the gender approaches. Second, following Esping-Andersen et al. (2013), whether couples are more likely to adopt more gender symmetry in their division of paid and unpaid work because of equity tensions or because they try to achieve more efficient outcomes.

This study examines how differences in partners' relative resources (education and labour market outcomes) and women's gender ideology may affect the division of unpaid work in one of the paradigms of the family-oriented regimes (Esping-Andersen, 1999). Therefore, I contrast two of the main theories explaining housework division: "doing gender" and human capital theory. For this purpose, I use the 2018 Fertility Survey of the Spanish National Statistics Institute (INE) in order to identify how these factors are related to significant variations in partners' housework division.

Compared to previous studies, this article offers two new contributions. First, because of the large sample size, I can explore the interaction between 
the educational level of both partners in nine possible combinations instead of analysing them independently. This detailed analysis is relevant for understanding the consequences of educational differences between partners as a result of the reversal of the gender gap in education. Second, I test whether women's gender ideology and the belief in the fairness of housework equity has any effect on housework division; something missing in studies published in recent years for the Spanish case, which normally relied on proxies.

Even if this dataset does not offer the same level of reliability and accuracy as time use surveys (TUS), and comparisons are not possible because of differences between indicators, it can still provide some hints from a different perspective that could be applied to further analyses using the next Spanish TUS.

\section{Background}

According to Becker's (1991) specialization theory, the partner with higher human capital (education, earnings, labour market experience) would devote their time to paid work while their spouse would focus on housework and childcare. Such a division of work is considered a process where partners seek to rationally maximize returns from household work and the labour market according to their relative productivities in each sphere. Because of differences in human capital accumulation resulting from different investments, women's housework productivity is higher than men's, and the opposite happens with market work productivity. Hence, men focus on paid work and women on running the household. In line with Becker's approach, the time availability perspective highlights that couples would also distribute unpaid work according to their time constraints depending on the amount of time spent in the labour market. Evidence supporting these lines of reasoning has shown that women's housework time was reduced when they spent time in paid work (Presser, 1994) or that housework dedication was less unequal when women were more educated or earned more than their male partners (Bianchi et al., 2000). Moreover, similar to Becker's position, the relative resources approach suggested that housework is allocated in a process of bargaining, where the relative labour market outcomes of the spouses determine their different contributions to household work (Blair and Lichter, 1991). Brines (1994) identified this asymmetrical allocation as a relationship of dependency, where women carry out most of the housework in exchange for the economic resources that their husbands provide.

However, these approaches have been shown to offer an insufficient explanation for the unequal share of productive and reproductive work. Critiques from feminist scholars and gendered perspectives such as "doing gender" or "gender display" claimed that the division of domestic work went beyond the rationality of economic and time constraints. In contrast, they argued that partners divide work following gender social constructs and behave accor- 
ding to the normative expectations of femininity and masculinity (West and Zimmerman, 1987; Coltrane, 2000). In support of these mechanisms, researchers have shown that the division of tasks and resources is not gender neutral. They have systematically found that women abandoned their jobs after marriage or motherhood (Blossfeld and Drobnic, 2001) or that men would dedicate less time to housework and enjoy more free time than their wives when both spouses were breadwinners (Hochschild and Machung, 1989). Other analyses suggested that men's housework would increase up to the point where wives earned more than them, remain stable after that threshold or even decrease (Greenstein, 2000; Bittman et al., 2003), even when men were long-term unemployed (Brines, 1994). Brinnes (1994) saw this as an example of "gender display", while Greenstein (2000) adopted the concept of "gender deviance neutralization" after observing that the relationship between economic dependence and housework performance was curvilinear instead of linear. He explained that when partners violate a gender norm, both of them compensate that social deviant behaviour by adopting more traditional roles and exaggerating their normative gender behaviour, thereby reaffirming their gender identities. Thus, when women become the main breadwinners, they would increase their housework performance and their husbands would reduce their amount of unpaid work. Nevertheless, other scholars have found opposite results, thus raising doubts about the validity of such conclusions (Bianchi et al., 2000; Kan, 2008), and suggested that they were only valid for specific groups (Sullivan, 2011) or national contexts (Evertsson and Nermo, 2004). Nonetheless, the rational specialization and gendered approaches can be considered complementary rather than competing frameworks, given that evidence commonly shows mixed and simultaneous support for both (Bianchi et al., 2000; Parkman, 2004; Davis et al., 2007).

According to other perspectives, work allocation seems to present big differences across countries (Davis and Greenstein, 2004). Some authors have emphasized the influence of macro-level factors and institutional arrangements as determinants of the unequal division of paid and unpaid work (Fuwa, 2004; Stier and Lewin-Epstein, 2007; Esping-Andersen, 2009). Thus, the rationality behind relative resources and specialization only prevails in very egalitarian and very traditional contexts (Esping-Andersen, 2009; Aasve et al., 2014). Within the framework of multiple equilibria, Esping-Andersen et al. (2013) compared couples' dedication to paid work and housework in Spain, the UK and Denmark; three paradigms of the Southern European, liberal and socialdemocratic regimes, respectively. In each of these, they discovered a different dominant equilibrium depending on the symmetry of the partners' distribution of paid and unpaid work. While in Denmark a gender-egalitarian equilibrium predominated (both partners equally sharing paid and unpaid work), the UK was characterized by a prevalence of the unstable equilibrium (both partners breadwinning and women also doing most of the chores). Spain was dominated by a traditional equilibrium (men breadwinners and women housekeepers), followed by an unstable equilibrium, with almost no sign of egalitarian cou- 
ples. Evidence of doing gender was found in the UK and Spain, where men who were very dependent on their wive's earnings or men who were the main providers did less housework than expected, while the opposite situation was found in the egalitarian Danish context.

\subsection{Gender-egalitarian attitudes and education}

The relevance of gender-egalitarian attitudes has usually been studied from the gender perspective and shown that socialization and the social construction of gender affects the division of housework. Researchers have found that egalitarian beliefs have a negative effect on women's housework in both micro-level (Bianchi et al., 2000) and macro-level analyses (Aasve et al., 2014). Some results reflect that these micro-level negative relationships persist even when controlling for macro-level variables such as welfare regime (Geist, 2005) or country (Davis et al., 2007), and that its effect is stronger in countries that are more gender egalitarian (Fuwa, 2004). Others instead highlight that the influence of ideology only works at the micro and macro levels for women and is significant for men only at the country-level (Treas and Tai, 2016). Carriero and Todesco (2018) pointed out that a woman's gender egalitarian attitudes are related to a relevant reduction of housework if her earnings are equal to or larger than the man's or if she is highly educated, independently of her earnings. Greenstein (1996) determined that couples' egalitarian beliefs interact, showing that men's gender ideology had little or no improvement in housework dedication if one of them was very traditional, whereas an egalitarian division was achieved when both shared egalitarian beliefs. An alternative view also suggests that men's gender ideology could be a stronger predictor of housework division than women's gender ideology (Pittman and Blanchard, 1996; Kroska, 2004).

Researchers have consistently found that both highly educated men and women are more egalitarian in their housework allocation (see Coltrane, 2000). While lower domestic work among highly educated women could be explained by higher career orientation, resources and gender-egalitarian attitudes, only the latter factor is usually argued to justify men's higher contribution (Shelton and John, 1996). Hence, men with a college education would show more gender-egalitarian behaviours due to their greater gender-egalitarian attitudes, which are determined by higher education attainment. Nonetheless, the results offer mixed evidence when studying the relationship between their housework involvement and gender ideology. It is not clear whether educational attainment captures the whole variance explained by their gender attitudes or if these operate independently. Analyses usually show that education and gender egalitarian attitudes are significantly and positively related to men's performance when these two indicators are included together in the models (Presser, 1994; Greenstein, 1996; Pittman and Blanchard, 1996; Bianchi et al., 2000; Fuwa, 2004; Nordenmark, 2014). But other analyses reveal that there is an effect of gender ideology but not of college (Davis et al., 2007; Treas and 
Tai, 2016) and some evidence points to no effect for either of the two variables (Greenstein, 2000).

\subsection{The case of Spain}

The existence of a traditional pattern and the asymmetric division of work in Spain was already documented in an analysis of the 1991 TUS (Álvarez and Miles, 2003). More recently, Sevilla-Sanz et al. (2010) studied the 2002-2003 Spanish TUS and found strong evidence of doing gender. Consistent with the previously mentioned studies, men's housework increased along with women's rising relative earnings, but remained constant after women's earnings surpassed men's. Instead, higher educational attainment for both partners entailed lower shares of housework for the wife. Again, men's housework seemed not to grow at the same rate as women's bargaining power. Another analysis of the Spanish TUS comparing 2002-2003 and 2009-2010 (Moreno-Colom et al., 2018) similarly determined that having children meant a significant increase in housework dedication for women but no significant change for men. In line with the international evidence, the authors observed that more education for women entailed less domestic work, whereas the effect was smaller and positive for men.

Another qualitative study of cohabiting childless partners in Spain (Domínguez-Folgueras et al., 2016) showed that some couples share their housework independently of their partners' time availability, whereas housework division was dependent on paid work for others. When women had more or the same resources than men but less available time, the division of chores was nontraditional, even when men were reluctant to do unpaid work. The belief in the fairness of equality was identified as an important factor for equality but equal resources was not.

\section{Hypotheses}

Following specialization and rational allocation theories, couples should divide housework according to their relative resources, aiming to maximize their different productivities: time devoted to chores should be related to differences in relative education, differences in the amount of paid work and relative incomes. Therefore, when women are more educated than men, work more than them and have higher salaries, their housework shares decline (Hypothesis 1).

Results in line with the gender theories should reflect two possible mechanisms: partners resist performing non-traditional roles (gender display) or they adopt compensatory behaviours when a gender norm is broken (gender deviance neutralization). Thus, when women work more and have higher earnings than men, their housework allocation increases or remains constant (Hypothesis 2).

With respect to educational differences, if we consider that women who are more educated than their male partners are breaking a gender norm (because 
of their access to higher occupational status, social capital and cultural capital) then gender theories identify different mechanisms that would predict different results. Similarly to Hypothesis 2, gender deviance neutralization and gender display would explain that when women are hypogamous, their housework performance increases or remains constant. However, gender approaches would also consider that hypogamous women would do less housework as a result of greater gender-egalitarian attitudes among the highly educated. Since this same result would also be expected by the specialization framework, only the effect of gender attitudes would help to identify the real mechanism behind this. Therefore, if the effects of hypogamy disappear after controlling for gender attitudes, gender ideology could be recognized as the main determinant. Instead, in the opposite situation (when hypogamy is significant while gender attitudes are not), the main effect would be caused by educational differences, without the influence of gender ideology.

Third, consistently with previous findings, attitudes towards traditional gender norms should have a negative impact on the amount of housework done by women. Thus, after controlling for potential confounders, gender egalitarian beliefs are related to less housework contribution (Hypothesis 3).

\section{Data and methods}

Even if it is necessary to account for different limitations, the Fertility Survey of 2018 conducted by the Spanish National Institute of Statistics contains updated data as well as variables related to gender-egalitarian values and beliefs. The survey comprises information on more than 14,000 women aged 18-55 and an independent sample of more than 2,000 men that were interviewed in 2018 following a two-stage sampling process. One the one hand, it contains an extremely low number of missing values in most of the variables. On the other, the characteristics of the main dependent variable make it difficult to draw unequivocal conclusions, and results should be interpreted as hints for future analyses with more accurate datasets. In the survey, housework division is captured in the response to the question "Regarding the time devoted to housework, could you tell me what percentage is done by you, what percentage is done by your partner and what percentage is done by another person?", where the interviewees had to give three answers that amounted to one hundred. It is important to note that variables regarding partner characteristics were also provided by the interviewees instead of by the partners themselves, and that the interviewees and their partners did not exactly share the same variables and their coding. For this reason, I decided to work only with the larger sample, which in this case was the sample of women.

The sample was restricted to women in heterosexual relationships cohabiting with their partners and only to households inhabited by two partners or two partners and their kids, thus avoiding households with the presence of other relatives that may distort the division and amount of housework. I discarded households without income and those in which both partners are 
unemployed, but I did not restrict my analyses to dual-earner couples. I excluded observations where at least one of the partners reported their main activity to be "student", "unable to work", "retired" or "other kind of inactivity". Finally, I only analysed couples where the housework shares of both partners together would amount to at least $40 \%$ (where the rest of the housework is done by the other person). ${ }^{1}$ As the presence of a third person doing housework could distort the results, I re-scaled the percentages of housework for men and women, discounting the percentage done by other individuals. Although most of the respondents reported a percentage rounded to the closest decile, some chose values in between. Because this scaling between values could affect the normality assumption, I recoded housework percentage in ten even categories and the intermediate values were reassigned to the closest lower decile.

Previous investigations provide an interesting contrast between the interviewees' own estimations and those obtained from the more precise TUS. Although some authors have pointed out that both partners tend to overestimate their own housework time, with a much higher overestimation by men compared to women (Press and Townsley, 1998), Bonke (2005) indicated that both partners tend to underestimate their unpaid work and did not observe significant differences by gender. Kan (2008) indicated that women tended to report significantly more accurate results than men, while males had a tendency to overreport. In line with these results, Carrasco and Dominguez (2015) studied the Spanish case and provided evidence that women were more accurate than men in reporting housework and that their answers presented low variability between surveys. ${ }^{2}$ To the best of my knowledge, no studies have tested the reliability of housework reported as a percentage.

\subsection{Independent variables}

Below, I explain the selection of covariates and the frequencies shown in Table 1. In some cases, variables were included as relative measures for both partners, while in other cases the low number of observations did not allow this codification. Broadly, the selection of covariates follows that of other studies (i.e. Moreno-Colom et al., 2018 and Sevilla-Sanz et al., 2010)

Education: To properly show the possible associations of couple composition on housework, the partners' level of education reflects both the absolute level of education and the relative differences. Hence, the large sample size allowed the categorization of all the different compositions of couples for

1. Although the restriction may seem arbitrary, it was necessary to set a threshold (some couples reported no housework done by themselves), and this entailed a loss of less than $1 \%$ of the total sample.

2. To assess how women and men report housework shares differently, I simply compared the housework reported by the sample of women with that reported by the sample of men. The estimations are remarkably similar between groups and both men and women agree that women do most of the housework. Nonetheless, women report that they do a higher share than that reported by men for their female partners. 
Table 1. Main sample and variables characteristics

\begin{tabular}{|c|c|c|}
\hline & Observations / Mean (SD) & Weighted frequencies \\
\hline \multicolumn{3}{|l|}{ Paid help } \\
\hline No & 6442 & 91.35 \\
\hline Yes & 589 & 8.65 \\
\hline \multicolumn{3}{|l|}{ Demographic variables } \\
\hline \multirow[t]{2}{*}{ Number of kids (0-3) } & 0.2 & \\
\hline & $(0.4)$ & \\
\hline \multirow[t]{2}{*}{ Number of kids (4-9) } & 0.4 & \\
\hline & $(0.6)$ & \\
\hline \multirow[t]{2}{*}{ Number of kids (10+) } & 0.8 & \\
\hline & $(0.9)$ & \\
\hline \multicolumn{3}{|l|}{ Women's immigrant status } \\
\hline Native & 6298 & 86.46 \\
\hline Long-term resident & 330 & 6.16 \\
\hline Short-term resident & 403 & 7.38 \\
\hline \multicolumn{3}{|l|}{ Men's immigrant status } \\
\hline Native & 6382 & 83.79 \\
\hline Long-term resident & 331 & 6.26 \\
\hline Short-term resident & 318 & 9.95 \\
\hline \multirow[t]{2}{*}{ Years cohabiting } & 15.9 & \\
\hline & (8.6) & \\
\hline \multirow[t]{2}{*}{ Women's age } & 42.6 & \\
\hline & $(7.5)$ & \\
\hline \multirow[t]{2}{*}{ Age difference } & 2.2 & \\
\hline & (3.9) & \\
\hline \multicolumn{3}{|l|}{ Women's student status } \\
\hline Yes & 686 & 9.79 \\
\hline No & 6345 & 90.21 \\
\hline \multicolumn{3}{|l|}{ Pregnancy status } \\
\hline Not pregnant & 6822 & 96.77 \\
\hline Pregnant & 209 & 3.23 \\
\hline \multicolumn{3}{|l|}{ Relative resources } \\
\hline \multicolumn{3}{|l|}{ Relative education } \\
\hline Both low & 1122 & 15.65 \\
\hline Women up. sec., men low & 825 & 11.33 \\
\hline Women university, men low & 322 & 4.13 \\
\hline Men up. sec., women low & 464 & 6.27 \\
\hline Both upper secondary & 1536 & 22.86 \\
\hline Women university, men up. sec. & 951 & 13.25 \\
\hline Men university, women low & 91 & 1.16 \\
\hline Men university, women up. sec. & 438 & 6.50 \\
\hline Both university & 1282 & 18.86 \\
\hline
\end{tabular}


Table 1. Main sample and variables characteristics (continued)

\begin{tabular}{|c|c|c|}
\hline & Observations / Mean (SD) & Weighted frequencies \\
\hline \multicolumn{3}{|l|}{ Women's relative income } \\
\hline $0-19 \%$ & 1463 & 20.65 \\
\hline $20-39 \%$ & 1224 & 17.58 \\
\hline $40-59 \%$ & 3467 & 49.44 \\
\hline $60-79 \%$ & 598 & 8.46 \\
\hline $80-100 \%$ & 261 & 3.87 \\
\hline \multicolumn{3}{|l|}{ Household income $(€)$} \\
\hline Less than 500 & 244 & 3.20 \\
\hline 500 to less than 1000 & 508 & 7.59 \\
\hline 1000 to less than 1500 & 1254 & 18.78 \\
\hline 1500 to less than 2000 & 1231 & 17.36 \\
\hline 2000 to less than 2500 & 1317 & 18.42 \\
\hline 2500 to less than 3000 & 802 & 11.00 \\
\hline 3000 to less than 5000 & 1176 & 16.20 \\
\hline More than 5000 & 499 & 7.45 \\
\hline \multirow[t]{2}{*}{ Women's seniority (years) } & 8.2 & \\
\hline & (8.9) & \\
\hline \multicolumn{3}{|l|}{ Relative working time } \\
\hline Men more than women & 2865 & 40.34 \\
\hline Both Equal & 3688 & 52.52 \\
\hline Women more than men & 478 & 7.14 \\
\hline \multicolumn{3}{|l|}{ Men's job sector } \\
\hline Unemployed & 317 & 4.67 \\
\hline Public & 1350 & 18.59 \\
\hline Private & 5364 & 76.74 \\
\hline \multicolumn{3}{|l|}{ Women's job sector } \\
\hline Unemployed & 1825 & 26.07 \\
\hline Public & 1280 & 16.98 \\
\hline Private & 3926 & 56.95 \\
\hline \multicolumn{3}{|l|}{ Gender attitudes } \\
\hline \multicolumn{3}{|l|}{ Housework fairness } \\
\hline Egalitarian & 6493 & 91.66 \\
\hline Non-egalitarian & 538 & 8.34 \\
\hline
\end{tabular}

Source: Own elaboration using the Fertility Survey (Spain) of 2018, INE.

three different levels of education: lower secondary or compulsory education (ISCED 1-3), upper secondary and vocational training (ISCED 4-6) and university (ISCED 7-9).

Immigrant status: The selection of this covariate is due to the possible cultural differences between locals and foreigners. The classification of immigrants posed two problems derived from the low (but still representative) number of observations. 
Thus, my classification only differentiates between long-term and shortterm residents because of the possible convergence with locals in the division of work (Hwang, 2016). I classified as "long-term residents" those immigrants that had lived in Spain for at least 15 years and those that had lived in Spain less than 15 years but spent half or more of their life in the country. I then classified people that moved to Spain less than 15 years ago and have spent less than the $50 \%$ of their life in the country as "short-term residents". However, it should this classification is imperfect, and this variable should be considered exclusively as a control, without drawing any direct conclusions.

Number of kids: Three different variables were included for different age ranges; number of kids from 0 to 3 , from 4 to 9 , and 10 or more. Previous studies have usually found that the higher the number of kids, the more women are involved in housework (Aasve et al., 2014; Moreno-Colom et al., 2018).

Women's age: Looking for non-linearities, women's age squared was also tested, but neither the square nor the non-squared variable showed significant results.

Age difference: This variable is interpreted as "age of women minus age of men". Instead of including age of men, age difference avoids problems of collinearity with women's age.

Years cohabiting: Included as a control variable, I expected it to affect housework division because of possible behavioural changes between partners. Collinearity with women's age was not strong.

Student status: Included as a control for time availability, it reflects a situation where women are students but not "students" as main activity. This variable was not provided for men.

Pregnancy status: This dichotomous variable was included as a control under the assumption that pregnant women may decrease their usual housework dedication because of higher physical fatigue.

Income shares: Income was presented for each partner as an ordinal variable (9 categories, from "no income" to "€ $€ 5000$ or more"), from where I obtained "women's income shares" dividing women's income by the income of men and women. Then I set quintiles, using income shares as a categorical variable to detect non-linearities.

Household income: This included 9 categories from "no income" to "€5000 or more". I also tested household income squared but it was finally discarded due to lack of significance. This variable was included based on the evidence that households with higher incomes might be able to outsource more (Sevilla-Sanz et al., 2010) or have better access to domestic technologies (Heisig, 2011).

Differences in working time: This variable reflects which partner has a longer work schedule than the other and is coded as: "both equal" (both partners employed full time or part time), "women more" (men unemployed and women working part time or full time, or men working part time and women full time) and "men more" (women unemployed and men working part time or full time, or women working part time and men full time). While for 
women it was always possible to differentiate whether they were working part time or full time, ${ }^{3}$ self-employed men were not classified under this variable. Because of the general evidence of less leisure time availability for this group of workers (Konietzko, 2015; Molina et al., 2016) and the fact that the opposite seems to be found for women (Gimenez-Nadal et al., 2012), they were coded as full-timers.

Paid help: Since the share of housework done by a third person had been already subtracted, this dichotomous variable captured whether the existence of paid help has any incidence in the share of housework.

Women's seniority: This variable capture the number of years that women spent in their current job as a proxy for career commitment. If women have more career obligations, responsibilities or commitments towards their organization, they might face a higher opportunity cost in doing housework. The equivalent for men was not available.

Job sector: Evidence shows that split work schedules are more frequent in the private sector and that they may influence time availability (AmuedoDorantes and De la Rica, 2009; Gracia and Kalmijn, 2016).

Gender egalitarian attitudes: Among the different indicators available in the survey, I identified three variables that clearly reflected egalitarian attitudes and beliefs in the form of the following statements: (1) "if the woman earns more than her partner, that is not good for the relationship", (2) "when jobs are scarce, men should have more right to a job than women" and (3) "men should participate in housework as much as women". I coded them as dummies, reflecting egalitarian values (disagree versus other for the first two, agree versus other for the last one $e^{4}$ ). Then, I tested the predictive power of each variable alone by including them in basic models - controlling for paid help and demographic variables - with education (results in Table 4 of the Appendix). Contrary to other studies, a significant association was found only for the variable relating to housework division, "men should participate in housework as much as women". Gender egalitarian attitudes were therefore captured only by the third indicator.

\subsection{Analytical strategy}

I used OLS regression to identify associations with housework shares, while shifting progressively from a basic model with relative education to a complete one. Then, as a sensitivity test, I replicated these previous models using a different dependent variable. In this case, reported housework shares were rounded up - rather than down - to the nearest decile. Finally, I explored the relationship between gender-egalitarian values and housework division in a series of incomplete models in order to avoid potential collinearities and

3. Because some allegedly part-timers' women were working even 40 hours a week, I classified as full-timers all those women working more than 30 hours per week.

4. The response options were "agree", "disagree" or "neither agree nor disagree". 
overfitting issues. Nevertheless, collinearity was tested in all the models, and always showed acceptable values. Before the analysis, I found it necessary to test the hypothesis that partners might be splitting the unpaid work between housework and childcare (for example, each partner taking care of either housework or childcare only). The codification of childcare made it possible to elaborate two indicators. First, as a raw measure of activities done by women minus activities done by men; second, the proportion of activities done by women (expressed as a percentage of the total number of activities done by both parents). Then they were included both alone and as squared terms in the complete models (excluding gender ideology). The sample excluded couples with women on maternal leaves and kids that were self-sufficient. All the terms presented positive coefficients, which allowed me to conclude that women's involvement in childcare and housework were positively correlated and discard the possibility that each partner could be doing either childcare or housework.

\section{Results}

\subsection{Descriptive statistics}

The descriptive statistics in Table 2 clearly reflect that, on average, women report doing most of the housework, regardless of their relative resources or the presence of children. For example, looking at relative education, there is a difference of 6 percentage points (pp) between the highest and the lowest mean value for mothers, and $15 \mathrm{pp}$ for the group of non-mothers. Relative working time reflects a difference of $11 \mathrm{pp}$ for childless women and $15 \mathrm{pp}$ for mothers between the categories "women working more than men" and "men working more than women". Looking at income shares, the difference between the lowest and the highest quintile is 12 and $17 \mathrm{pp}$ for mothers and non-mothers, respectively.

\subsection{OLS regression analysis}

The estimates in Table 3a reveal that the effect of all the basic control variables, except education, is very consistent across all the models. Unsurprisingly, having more kids, no matter the age interval, is related to an increase in female housework. The same happens for years of cohabitation. However, it is not the case for women's age, age difference, student status or pregnancy. The relationship with paid help is repeatedly related to less housework dedication for women.

The relationship of the relative education of the partners with housework division presents small differences between models. The first one reflects that, only in couples where women are highly educated and men have upper secondary education $(b=0.434)$, as well as for highly educated homogamous couples $(b=-0.418)$, women seem to be doing significantly less housework 
Table 2. Descriptive statistics. Women's reported housework by motherhood status

\begin{tabular}{|c|c|c|c|c|}
\hline \multirow[b]{2}{*}{ Relative education } & \multicolumn{2}{|c|}{ Childless } & \multicolumn{2}{|c|}{ Mothers } \\
\hline & Mean & SD & Mean & SD \\
\hline Both low & 72.7 & 18.1 & 72.0 & 19.0 \\
\hline Women up. sec., men low & 64.8 & 15.7 & 71.4 & 17.9 \\
\hline Women university, men low & 63.7 & 16.8 & 71.3 & 18.3 \\
\hline Men up. sec., women low & 68.1 & 19.0 & 70.8 & 19.3 \\
\hline Both upper secondary & 62.0 & 16.0 & 70.5 & 17.2 \\
\hline Women university, men up. sec. & 58.5 & 15.0 & 64.7 & 16.7 \\
\hline Men university, women low & 58.7 & 16.1 & 74.5 & 15.4 \\
\hline Men university, women up. sec. & 64.3 & 15.3 & 69.0 & 16.0 \\
\hline Both university & 57.9 & 13.4 & 65.4 & 15.4 \\
\hline \multicolumn{5}{|l|}{ Relative working time } \\
\hline Men more than women & 69.6 & 16.6 & 74.8 & 17.0 \\
\hline Both equal & 59.9 & 14.5 & 65.8 & 16.0 \\
\hline Women more than men & 58.0 & 20.2 & 59.5 & 21.3 \\
\hline \multicolumn{5}{|l|}{ Women's relative income } \\
\hline $0-19 \%$ & 72.0 & 17.6 & 77.2 & 16.4 \\
\hline $20-39 \%$ & 66.7 & 15.1 & 70.5 & 17.0 \\
\hline $40-59 \%$ & 59.8 & 14.9 & 66.5 & 16.3 \\
\hline $60-79 \%$ & 60.4 & 16.6 & 64.7 & 18.0 \\
\hline $80-100 \%$ & 60.2 & 19.2 & 59.7 & 23.1 \\
\hline \multicolumn{5}{|l|}{ Egalitarian attitudes } \\
\hline Non-egalitarian & 69.1 & 18.8 & 71.6 & 19.1 \\
\hline Egalitarian & 62.0 & 16.0 & 69.0 & 17.4 \\
\hline
\end{tabular}

Source: Own elaboration using the Fertility Survey (Spain) of 2018, INE.

than the reference group (homogamous with upper secondary education). No other couple composition shows a significant increase in housework for any of the categories. The introduction of income shares (Model 2) turns the negative coefficient for the category "men university education and women upper secondary" significant $(b=-0.196)$, although this association is less clear $(p<10 \%)$ once differences in working time are included. Household income is not related to variations in housework, but part of its explained variance could be captured by the variable paid help. Income quintiles reveal that women do significantly more housework as they lose bargaining power. However, men's housework only grows significantly when they earn between 0 and 20 percent of total income $(b=-0.602)$, whereas no significant increase is observed for the fourth quintile. Nevertheless, when job-related variables are introduced in Model 3, the relationship for the last quintile is no longer significant $(b=-0.205)$. Working time differences reflect that women increase their housework when men work more than them $(b=0.374)$, and men also increase theirs when women work longer than them $(b=-0.340)$ compared to couples with similar working hours. 
Table 3a. Estimates of OLS regression models: Effects on women's housework shares

\begin{tabular}{|c|c|c|c|c|}
\hline & $\begin{array}{c}\text { Model } 1 \\
\text { b/(se) }\end{array}$ & $\begin{array}{c}\text { Model } 2 \\
\text { b/(se) }\end{array}$ & $\begin{array}{c}\text { Model } 3 \\
\text { b/(se) }\end{array}$ & $\begin{array}{c}\text { Model } 4 \\
\text { b/(se) }\end{array}$ \\
\hline \multicolumn{5}{|l|}{ Paid help (ref. = no) } \\
\hline Yes & $\begin{array}{l}-0.342^{\star \star \star} \\
(0.07)\end{array}$ & $\begin{array}{l}-0.273^{\star \star \star} \\
(0.07)\end{array}$ & $\begin{array}{l}-0.192^{\star \star} \\
(0.07)\end{array}$ & $\begin{array}{l}-0.192^{\star \star} \\
(0.07)\end{array}$ \\
\hline \multicolumn{5}{|l|}{ Demographic variables } \\
\hline Number of kids $(0-3)$ & $\begin{array}{l}0.212^{\star \star \star} \\
(0.05)\end{array}$ & $\begin{array}{l}0.161^{\star \star \star} \\
(0.05)\end{array}$ & $\begin{array}{l}0.126^{\star} \\
(0.05)\end{array}$ & $\begin{array}{l}0.126^{\star \star} \\
(0.05)\end{array}$ \\
\hline Number of kids (4-9) & $\begin{array}{l}0.194^{\star \star \star} \\
(0.04)\end{array}$ & $\begin{array}{l}0.152^{\star \star \star} \\
(0.04)\end{array}$ & $\begin{array}{l}0.126^{\star \star \star} \\
(0.03)\end{array}$ & $\begin{array}{l}0.125^{\star \star \star} \\
(0.04)\end{array}$ \\
\hline Number of kids (10+) & $\begin{array}{l}0.163^{\star \star \star} \\
(0.03)\end{array}$ & $\begin{array}{l}0.113^{\star \star \star} \\
(0.03)\end{array}$ & $\begin{array}{l}0.107^{\star \star \star} \\
(0.03)\end{array}$ & $\begin{array}{l}0.106^{\star \star \star} \\
(0.03)\end{array}$ \\
\hline \multicolumn{5}{|c|}{ Women's immigrant status (Ref.=native) } \\
\hline Long-term resident & $\begin{array}{l}0.040 \\
(0.12)\end{array}$ & $\begin{array}{l}0.029 \\
(0.12)\end{array}$ & $\begin{array}{l}0.014 \\
(0.12)\end{array}$ & $\begin{array}{l}0.011 \\
(0.12)\end{array}$ \\
\hline Short-term resident & $\begin{array}{l}0.164 \\
(0.12)\end{array}$ & $\begin{array}{l}0.003 \\
(0.12)\end{array}$ & $\begin{array}{r}-0.017 \\
(0.11)\end{array}$ & $\begin{array}{r}-0.021 \\
(0.11)\end{array}$ \\
\hline \multicolumn{5}{|c|}{ Men's immigrant status (Ref.=native) } \\
\hline Long-term resident & $\begin{array}{r}-0.132 \\
(0.12)\end{array}$ & $\begin{array}{l}-0.117 \\
(0.12)\end{array}$ & $\begin{array}{l}-0.077 \\
(0.12)\end{array}$ & $\begin{array}{c}-0.078 \\
(0.11)\end{array}$ \\
\hline Short-term resident & $\begin{array}{c}-0.237\left(^{*}\right) \\
(0.14)\end{array}$ & $\begin{array}{r}-0.177 \\
(0.13)\end{array}$ & $\begin{array}{l}-0.191 \\
(0.13)\end{array}$ & $\begin{array}{r}-0.192 \\
(0.13)\end{array}$ \\
\hline Years cohabiting & $\begin{array}{l}0.017^{\star \star \star} \\
(0.00)\end{array}$ & $\begin{array}{l}0.014^{* *} \\
(0.00)\end{array}$ & $\begin{array}{l}0.013^{\star *} \\
(0.00)\end{array}$ & $\begin{array}{l}0.013^{* \star} \\
(0.00)\end{array}$ \\
\hline Women's age & $\begin{array}{l}0.005 \\
(0.01)\end{array}$ & $\begin{array}{l}0.005 \\
(0.01)\end{array}$ & $\begin{array}{l}0.008 \\
(0.01)\end{array}$ & $\begin{array}{l}0.008 \\
(0.01)\end{array}$ \\
\hline Age difference & $\begin{array}{l}0.001 \\
(0.01)\end{array}$ & $\begin{array}{c}-0.002 \\
(0.01)\end{array}$ & $\begin{array}{c}-0.002 \\
(0.01)\end{array}$ & $\begin{array}{c}-0.002 \\
(0.01)\end{array}$ \\
\hline \multicolumn{5}{|c|}{ Women's student status (Ref.=yes) } \\
\hline No & $\begin{array}{c}-0.046 \\
(0.08)\end{array}$ & $\begin{array}{r}-0.021 \\
(0.07)\end{array}$ & $\begin{array}{l}0.019 \\
(0.07)\end{array}$ & $\begin{array}{l}0.017 \\
(0.07)\end{array}$ \\
\hline \multicolumn{5}{|c|}{ Pregnancy status (Ref.=not pregnant) } \\
\hline Pregnant & $\begin{array}{r}-0.081 \\
(0.11)\end{array}$ & $\begin{array}{c}-0.166 \\
(0.11)\end{array}$ & $\begin{array}{c}-0.132 \\
(0.11)\end{array}$ & $\begin{array}{c}-0.134 \\
(0.11)\end{array}$ \\
\hline
\end{tabular}

Relative resources

Relative education (Ref. $=$ Both Upper Secondary/Vocational Training)

\begin{tabular}{|c|c|c|c|c|}
\hline Both low & $\begin{array}{l}0.121 \\
(0.08)\end{array}$ & $\begin{array}{c}-0.024 \\
(0.08)\end{array}$ & $\begin{array}{r}-0.047 \\
(0.08)\end{array}$ & $\begin{array}{c}-0.053 \\
(0.08)\end{array}$ \\
\hline \multirow[t]{2}{*}{ Women up. sec., men low } & 0.087 & 0.101 & 0.081 & 0.082 \\
\hline & $(0.08)$ & $(0.08)$ & $(0.08)$ & $(0.08)$ \\
\hline \multirow[t]{2}{*}{ Women university, men low } & 0.088 & 0.190 & 0.167 & 0.169 \\
\hline & $(0.12)$ & $(0.12)$ & $(0.12)$ & $(0.12)$ \\
\hline \multirow[t]{2}{*}{ Men up. sec., women low } & 0.040 & -0.072 & -0.100 & -0.100 \\
\hline & $(0.11)$ & $(0.10)$ & $(0.10)$ & $(0.10)$ \\
\hline Women university, men up. sec. & $\begin{array}{l}-0.434^{\star \star \star} \\
(0.08)\end{array}$ & $\begin{array}{l}-0.347^{\star \star \star} \\
(0.08)\end{array}$ & $\begin{array}{l}-0.321^{\star \star \star} \\
(0.08)\end{array}$ & $\begin{array}{l}-0.320^{\star \star \star} \\
(0.08)\end{array}$ \\
\hline
\end{tabular}


Table 3a. Estimates of OLS regression models: Effects on women's housework shares (continued)

\begin{tabular}{|c|c|c|c|c|}
\hline & $\begin{array}{c}\text { Model } 1 \\
\text { b/(se) }\end{array}$ & $\begin{array}{c}\text { Model } 2 \\
\text { b/(se) }\end{array}$ & $\begin{array}{c}\text { Model } 3 \\
\text { b/(se) }\end{array}$ & $\begin{array}{c}\text { Model } 4 \\
\text { b/(se) }\end{array}$ \\
\hline Men university, women low & $\begin{array}{c}0.310 \\
(0.19)\end{array}$ & $\begin{array}{c}0.080 \\
(0.18)\end{array}$ & $\begin{array}{c}0.040 \\
(0.18)\end{array}$ & $\begin{array}{c}0.041 \\
(0.18)\end{array}$ \\
\hline Men university, women up. sec. & $\begin{array}{r}-0.082 \\
(0.09)\end{array}$ & $\begin{array}{c}-0.196^{*} \\
(0.09)\end{array}$ & $\begin{array}{c}-0.167\left(^{*}\right) \\
(0.09)\end{array}$ & $\begin{array}{c}-0.166\left(^{*}\right) \\
(0.09)\end{array}$ \\
\hline Both university & $\begin{array}{l}-0.418^{\star \star \star} \\
(0.07)\end{array}$ & $\begin{array}{l}-0.361^{\star \star \star} \\
(0.07)\end{array}$ & $\begin{array}{l}-0.300^{\star \star \star} \\
(0.07)\end{array}$ & $\begin{array}{l}-0.298^{\star \star \star} \\
(0.07)\end{array}$ \\
\hline \multicolumn{5}{|c|}{ Women's relative income (Ref.= both between $40-59 \%)$} \\
\hline $0-19 \%$ & & $\begin{array}{l}0.900^{\star \star \star} \\
(0.06)\end{array}$ & $\begin{array}{l}0.365^{\star \star \star} \\
(0.08)\end{array}$ & $\begin{array}{l}0.363^{* \star *} \\
(0.08)\end{array}$ \\
\hline $20-39 \%$ & & $\begin{array}{l}0.369^{\star \star \star} \\
(0.06)\end{array}$ & $\begin{array}{l}0.168^{\star \star} \\
(0.06)\end{array}$ & $\begin{array}{l}0.166^{\star \star} \\
(0.06)\end{array}$ \\
\hline $60-79 \%$ & & $\begin{array}{c}-0.113 \\
(0.08)\end{array}$ & $\begin{array}{l}0.032 \\
(0.09)\end{array}$ & $\begin{array}{l}0.030 \\
(0.09)\end{array}$ \\
\hline $80-100 \%$ & & $\begin{array}{l}-0.602^{* * *} \\
(0.15)\end{array}$ & $\begin{array}{c}-0.205 \\
(0.16)\end{array}$ & $\begin{array}{c}-0.208 \\
(0.16)\end{array}$ \\
\hline Household income & & & $\begin{array}{r}-0.003 \\
(0.01)\end{array}$ & $\begin{array}{c}-0.003 \\
(0.01)\end{array}$ \\
\hline Women's seniority & & & $\begin{array}{r}-0.004 \\
(0.00)\end{array}$ & $\begin{array}{r}-0.004 \\
(0.00)\end{array}$ \\
\hline \multicolumn{5}{|c|}{ Relative working time (Ref. = both equal) } \\
\hline Men more than women & & & $\begin{array}{l}0.374^{\star \star \star} \\
(0.07)\end{array}$ & $\begin{array}{l}0.375^{\star \star \star} \\
(0.07)\end{array}$ \\
\hline Women more than men & & & $\begin{array}{c}-0.340^{\star} \\
(0.15)\end{array}$ & $\begin{array}{c}-0.340^{*} \\
(0.15)\end{array}$ \\
\hline \multicolumn{5}{|l|}{ Men's job sector (Ref.=public) } \\
\hline Unemployed & & & $\begin{array}{r}-0.167 \\
(0.22)\end{array}$ & $\begin{array}{c}-0.164 \\
(0.22)\end{array}$ \\
\hline Private & & & $\begin{array}{l}0.142^{\star \star} \\
(0.05)\end{array}$ & $\begin{array}{l}0.141^{\star *} \\
(0.05)\end{array}$ \\
\hline \multicolumn{5}{|l|}{ Women's job sector (Ref.=public) } \\
\hline Unemployed & & & $\begin{array}{l}0.262^{\star} \\
(0.11)\end{array}$ & $\begin{array}{l}0.256^{\star} \\
(0.11)\end{array}$ \\
\hline Private & & & $\begin{array}{c}-0.040 \\
(0.06)\end{array}$ & $\begin{array}{r}-0.041 \\
(0.06)\end{array}$ \\
\hline \multicolumn{5}{|l|}{ Gender attitudes } \\
\hline \multicolumn{5}{|l|}{ Housework fairness (Ref.= Egalitarian) } \\
\hline Non-egalitarian & & & & $\begin{array}{l}0.105 \\
(0.09)\end{array}$ \\
\hline Intercept & $\begin{array}{l}6.072^{\star \star \star} \\
(0.20) \\
\end{array}$ & $\begin{array}{l}5.966^{\star \star \star} \\
(0.20)\end{array}$ & $\begin{array}{l}5.727^{\star \star \star} \\
(0.22) \\
\end{array}$ & $\begin{array}{l}5.728^{\star \star \star} \\
(0.22)\end{array}$ \\
\hline $\mathrm{R} 2$ & 0.060 & 0.115 & 0.142 & 0.142 \\
\hline $\mathrm{N}$ & 7031 & 7031 & 7031 & 7031 \\
\hline
\end{tabular}

Note: $\left(^{*}\right) p<0.10,{ }^{\star} p<0.05,{ }^{* *} p<0.01,{ }^{* * *} p<0.001$. Weights provided by the survey and heteroskedasticity-robust indicators have been used in the analysis.

Source: Own elaboration using the Fertility Survey (Spain) of 2018, INE. 
Table 3b. Estimates of OLS regression models: Effects on women's housework shares

\begin{tabular}{|c|c|c|c|c|c|}
\hline & $\begin{array}{c}\text { Model } 5 \\
\text { b/(se) }\end{array}$ & $\begin{array}{c}\text { Model } 6 \\
\text { b/(se) }\end{array}$ & $\begin{array}{c}\text { Model } 7 \\
\text { b/(se) }\end{array}$ & $\begin{array}{c}\text { Model } 8 \\
\text { b/(se) }\end{array}$ & $\begin{array}{c}\text { Model } 9^{1} \\
\text { b/(se) }\end{array}$ \\
\hline \multicolumn{6}{|l|}{ Paid help (ref. $=$ no) } \\
\hline Yes & $\begin{array}{l}-0.339^{\star \star \star} \\
(0.07)\end{array}$ & $\begin{array}{l}-0.266^{\star \star \star} \\
(0.07)\end{array}$ & $\begin{array}{l}-0.297^{\star \star \star} \\
(0.07)\end{array}$ & $\begin{array}{l}-0.224^{\star \star} \\
(0.07)\end{array}$ & $\begin{array}{l}-0.313^{\star \star \star} \\
(0.07)\end{array}$ \\
\hline \multicolumn{6}{|l|}{ Demographic variables } \\
\hline Number of kids $(0-3)$ & $\begin{array}{l}0.212^{\star \star \star} \\
(0.05)\end{array}$ & $\begin{array}{l}0.162^{\star \star \star} \\
(0.05)\end{array}$ & $\begin{array}{l}0.108^{\star} \\
(0.05)\end{array}$ & $\begin{array}{l}0.133^{\star \star} \\
(0.05)\end{array}$ & $\begin{array}{l}0.190^{\star \star} \\
(0.06)\end{array}$ \\
\hline Number of kids (4-9) & $\begin{array}{l}0.189^{\star \star \star} \\
(0.04)\end{array}$ & $\begin{array}{l}0.149^{\star \star \star} \\
(0.04)\end{array}$ & $\begin{array}{l}0.119^{\star \star \star} \\
(0.04)\end{array}$ & $\begin{array}{l}0.141^{\star \star \star} \\
(0.04)\end{array}$ & $\begin{array}{l}0.184^{\star \star \star} \\
(0.04)\end{array}$ \\
\hline Number of kids $(10+)$ & $\begin{array}{l}0.161^{\star \star \star} \\
(0.03)\end{array}$ & $\begin{array}{l}0.113^{\star \star \star} \\
(0.03)\end{array}$ & $\begin{array}{l}0.115^{\star \star \star} \\
(0.03)\end{array}$ & $\begin{array}{l}0.120^{\star \star \star} \\
(0.03)\end{array}$ & $\begin{array}{l}0.148^{\star \star \star} \\
(0.03)\end{array}$ \\
\hline \multicolumn{6}{|c|}{ Women immigrant status (Ref.=native) } \\
\hline Long term resident & $\begin{array}{c}0.032 \\
(0.12)\end{array}$ & $\begin{array}{l}0.023 \\
(0.12)\end{array}$ & $\begin{array}{c}0.020 \\
(0.12)\end{array}$ & $\begin{array}{c}0.014 \\
(0.12)\end{array}$ & $\begin{array}{c}0.136 \\
(0.17)\end{array}$ \\
\hline Short-term resident & $\begin{array}{c}0.152 \\
(0.12)\end{array}$ & $\begin{array}{c}-0.007 \\
(0.12)\end{array}$ & $\begin{array}{c}-0.017 \\
(0.11)\end{array}$ & $\begin{array}{c}0.049 \\
(0.12)\end{array}$ & $\begin{array}{c}-0.098 \\
(0.17)\end{array}$ \\
\hline \multicolumn{6}{|c|}{ Men immigrant status (Ref.=native) } \\
\hline Long term resident & $\begin{array}{c}-0.134 \\
(0.12)\end{array}$ & $\begin{array}{c}-0.119 \\
(0.12)\end{array}$ & $\begin{array}{c}-0.060 \\
(0.12)\end{array}$ & $\begin{array}{c}-0.079 \\
(0.12)\end{array}$ & $\begin{array}{c}-0.203 \\
(0.16)\end{array}$ \\
\hline Short-term resident & $\begin{array}{c}-0.239\left(^{*}\right) \\
(0.14)\end{array}$ & $\begin{array}{l}-0.179 \\
(0.13)\end{array}$ & $\begin{array}{c}-0.204 \\
(0.13)\end{array}$ & $\begin{array}{c}-0.218 \\
(0.13)\end{array}$ & $\begin{array}{c}-0.298 \\
(0.18)\end{array}$ \\
\hline Years cohabiting & $\begin{array}{l}0.017^{\text {** }} \\
(0.00)\end{array}$ & $\begin{array}{l}0.014^{* *} \\
(0.00)\end{array}$ & $\begin{array}{l}0.018^{\star * \star} \\
(0.00)\end{array}$ & $\begin{array}{l}0.014^{\star *} \\
(0.00)\end{array}$ & $\begin{array}{l}0.020^{* \star} \\
(0.01)\end{array}$ \\
\hline Women's age & $\begin{array}{l}0.005 \\
(0.01)\end{array}$ & $\begin{array}{l}0.005 \\
(0.01)\end{array}$ & $\begin{array}{l}0.005 \\
(0.01)\end{array}$ & $\begin{array}{l}0.006 \\
(0.01)\end{array}$ & $\begin{array}{r}-0.001 \\
(0.01)\end{array}$ \\
\hline Age difference & $\begin{array}{c}0.001 \\
(0.01)\end{array}$ & $\begin{array}{c}-0.002 \\
(0.01)\end{array}$ & $\begin{array}{c}-0.001 \\
(0.01)\end{array}$ & $\begin{array}{c}-0.003 \\
(0.01)\end{array}$ & $\begin{array}{l}0.003 \\
(0.01)\end{array}$ \\
\hline \multicolumn{6}{|c|}{ Women's student status (Ref.=yes) } \\
\hline No & $\begin{array}{c}-0.052 \\
(0.08)\end{array}$ & $\begin{array}{c}-0.025 \\
(0.07)\end{array}$ & $\begin{array}{l}0.073 \\
(0.07)\end{array}$ & $\begin{array}{l}0.008 \\
(0.07)\end{array}$ & $\begin{array}{l}0.068 \\
(0.10)\end{array}$ \\
\hline \multicolumn{6}{|c|}{ Pregnancy status (Ref.=not pregnant) } \\
\hline Pregnant & $\begin{array}{c}-0.086 \\
(0.11)\end{array}$ & $\begin{array}{c}-0.169 \\
(0.11)\end{array}$ & $\begin{array}{c}-0.105 \\
(0.11)\end{array}$ & $\begin{array}{c}-0.122 \\
(0.11)\end{array}$ & $\begin{array}{c}0.057 \\
(0.14)\end{array}$ \\
\hline
\end{tabular}

\section{Relative resources}

Relative education $($ Ref. $=$ Both Upper Secondary/Vocational Training)

Both low

$0.106-0.037$

$-0.036$

$(0.08) \quad(0.08)$

$(0.08)$

Women up. sec., men low

$0.091 \quad 0.101$

0.081

$(0.08)$

$(0.08)$

$(0.08)$

Women university, men low

$0.096 \quad 0.197\left(^{*}\right)$

0.152

$(0.12) \quad(0.12)$

(0.12)

Men up. sec., women low

$0.038-0.074$

$-0.070$

(0.11) $\quad(0.10)$

(0.11)

Women university, men up. sec.

$-0.431^{\star \star \star}-0.341^{\star \star \star}$

$-0.342^{\star \star \star}$

$(0.08) \quad(0.08)$

(0.08) 
Table 3b. Estimates of OLS regression models: Effects on women's housework shares (continued)

\begin{tabular}{|c|c|c|c|c|c|}
\hline & $\begin{array}{c}\text { Model } 5 \\
\text { b/(se) }\end{array}$ & $\begin{array}{c}\text { Model } 6 \\
\text { b/(se) }\end{array}$ & $\begin{array}{c}\text { Model } 7 \\
\text { b/(se) }\end{array}$ & $\begin{array}{c}\text { Model } 8 \\
\text { b/(se) }\end{array}$ & $\begin{array}{c}\text { Model } 9^{1} \\
\text { b/(se) }\end{array}$ \\
\hline \multirow[t]{2}{*}{ Men university, women low } & 0.308 & 0.082 & & 0.086 & \\
\hline & $(0.19)$ & $(0.18)$ & & $(0.18)$ & \\
\hline \multirow[t]{2}{*}{ Men university, women up. sec. } & -0.080 & $-0.190^{*}$ & & -0.132 & \\
\hline & $(0.09)$ & $(0.09)$ & & $(0.09)$ & \\
\hline \multirow[t]{2}{*}{ Both university } & $-0.413^{\star \star \star}$ & $-0.351^{\star \star \star}$ & & $-0.309^{\star * *}$ & \\
\hline & $(0.07)$ & $(0.07)$ & & $(0.07)$ & \\
\hline \multicolumn{6}{|c|}{ Women's relative income (Ref.= Both between $40-59 \%$ ) } \\
\hline \multirow[t]{2}{*}{$0-19 \%$} & & $0.885^{\star \star \star}$ & & & \\
\hline & & $(0.06)$ & & & \\
\hline \multirow[t]{2}{*}{$20-39 \%$} & & $0.362^{\star \star \star}$ & & & \\
\hline & & $(0.06)$ & & & \\
\hline \multirow[t]{2}{*}{$60-79 \%$} & & -0.115 & & & \\
\hline & & $(0.08)$ & & & \\
\hline \multirow[t]{2}{*}{$80-100 \%$} & & $-0.610^{\star \star \star}$ & & & \\
\hline & & $(0.15)$ & & & \\
\hline \multirow[t]{2}{*}{ Household income } & & -0.006 & & & \\
\hline & & $(0.01)$ & & & \\
\hline \multirow[t]{2}{*}{ Women's seniority } & & & -0.005 & & \\
\hline & & & $(0.00)$ & & \\
\hline \multicolumn{6}{|c|}{ Relative working time (Ref. = both equal) } \\
\hline \multirow[t]{2}{*}{ Men more than women } & & & $0.451^{\star * *}$ & & \\
\hline & & & $(0.07)$ & & \\
\hline \multirow[t]{2}{*}{ Women more than men } & & & $-0.315^{\star}$ & & \\
\hline & & & $(0.15)$ & & \\
\hline \multicolumn{6}{|l|}{ Men's job sector (Ref.=public) } \\
\hline \multirow[t]{2}{*}{ Unemployed } & & & -0.238 & $-0.694^{\star \star \star}$ & \\
\hline & & & $(0.21)$ & $(0.14)$ & \\
\hline \multirow[t]{2}{*}{ Private } & & & $0.176^{\star \star \star}$ & $0.148^{\star \star}$ & \\
\hline & & & $(0.05)$ & $(0.05)$ & \\
\hline \multicolumn{6}{|l|}{ Women's job sector (Ref.=public) } \\
\hline \multirow[t]{2}{*}{ Unemployed } & & & $0.493^{\star \star \star}$ & $0.878^{\star \star \star}$ & \\
\hline & & & $(0.09)$ & $(0.07)$ & \\
\hline \multirow[t]{2}{*}{ Private } & & & 0.013 & 0.037 & \\
\hline & & & $(0.06)$ & $(0.06)$ & \\
\hline
\end{tabular}

Gender attitudes

Housework fairness (Ref.= Egalitarian)

Non-egalitarian

$\begin{array}{lllll}0.248^{* *} & 0.154\left({ }^{*}\right) & 0.114 & 0.118 & 0.103\end{array}$

$\begin{array}{lllll}(0.09) & (0.09) \quad(0.09) \quad(0.09) \quad(0.13)\end{array}$

Intercept

$6.064^{\star \star *} 5.989^{\star \star \star} 5.545^{\star \star *} 5.773^{\star \star *} 5.812^{\star \star *}$

$\begin{array}{lccccc} & (0.20) & (0.21) & (0.20) & (0.21) & (0.25) \\ \text { R2 } & 0.062 & 0.116 & 0.130 & 0.127 & 0.035\end{array}$

$\begin{array}{llllll}\mathrm{N} & 7031 & 7031 & 7031 & 7031 & 3688\end{array}$

Note: $\left(^{*}\right) p<0.10,{ }^{*} p<0.05,{ }^{* \star} p<0.01,{ }^{* * *} p<0.001$. Weights provided by the survey and heteroskedasticity-robust indicators have been used in the analysis.

(1) This model only includes dual-breadwinner couples.

Source: Own elaboration using the Fertility Survey (Spain) of 2018, INE. 
Job sector variables indicate that women do significantly more housework when men work in the private sector $(b=0.142)$ compared to workers in the public sector, but no change in housework division is observed when men are unemployed $(b=-0.167)$. The opposite pattern is found for women's sector; women's unemployment increases their housework shares $(b=0.262)$, but no effect is seen for the private sector $(b=-0.040)$. In Model 4, egalitarian values present a non-significant relationship $(b=0.105)$ when included with all the covariates, while the rest of associations remain unaltered.

To sum up, the complete model shows that when accounting for the effect of all covariates, highly educated homogamous women $(b=-0.298)$ do less housework than medium educated homogamous women, whereas no significant difference is observed for the homogamous low educated $(b=-0.053)$. The effects of hypogamy and hypergamy appear to be mostly symmetric for both men and women. Compared to medium educated couples, couples in which one partner is highly educated and the other is low educated do not present significant differences in housework division. Neither do couples with one low educated partner and one with upper secondary education, regardless of whether the hypogamous partner is male or female. Therefore, the only significant decreases appear for couples in which one partner is highly educated and the other has higher or upper secondary education, although for hypergamous women the significance of this association is not fully clear $(b=-0.166)$. Household income has no association with housework $(b=-0.003)$ when accounting for paid help. Nonetheless, income quintiles suggest that women do more housework when their income contribution to the household is below $40 \%$, while men do not collaborate more in the house when women become the main breadwinners.

The replication models (Table 5a in the Appendix) yield the same results, since only a few differences can be observed for the labour market outcomes. In this case, it seemed that unemployed women did not perform significantly more housework than women working in the public sector $(b=0.230, p<10 \%)$. However, contrary to the previous models, when women worked more than men, apparently no significant decrease in housework was observed compared to couples in which both partners worked equally $(b=-0.283, p<10 \%)$. After all, both models seem to reflect two similar situations: the implications of unemployment and lower time constraints on household work performance are not equal for men and women. Men do less housework if they work less than women and the same amount of housework if they are unemployed. In contrast, women either do the same housework if they work more than men or they do more housework if they are unemployed. The replication models also showed that there is no significant decrease in housework when men are highly educated and women have upper secondary education $(b=-0.146$, the association was previously significant at the $10 \%$ level, and then there is no association at all). The socio-demographic variables yielded almost the same estimates: age was positively related to the dependent variable $(b=0.011, p<10 \%)$. Other small differences only existed in the non-complete models. 
The percentage of variance explained by each of these models is still relatively small. Consistent with findings from previous studies, the full model explains $14.2 \%$ of the total variance and the significant associations are small in substantive terms. For example, the housework shares of highly educated homogamous decreases from $3 \%$ to $5 \%{ }^{5}$ compared to their homogamous peers with upper secondary education. Similarly, compared to partners who have similar working schedules, housework allocation varies from 3\% to $4 \%$ when one of the partners works less.

Finally, in light of the elevated number of covariates and potential correlations, I tried to tease apart the effects of gender-egalitarian attitudes. I did so by studying this independent variable in a series of models that include the basic control variables and different sets of variables concerning the relative resources. Namely, I tested this association when variables about education (relative education), income (women's relative income and household income) and work (women's seniority, relative working time, men's job sector and women's job sector) are included separately in the basic model. In addition, I tested the association of egalitarian values by including in the model these groups of variables in pairs: (1) education and work variables, (2) education and income variables and (3) work and income variables (models in Table $3 b^{6}$ ).

The results in Table $3 \mathrm{~b}$ show that the association between egalitarian values and housework holds when controlling for education in Model $5(b=0.248)$ and probably education and income together in Model $6(b=0.154, p<10 \%)$. In short, education and income do not capture the variance explained by egalitarian values. Instead, in Model 7 the association between gender values and housework disappears once labour market variables are controlled for $(b=0.114)$. In particular, simply by including variables related to job sector (which also includes unemployment) in Model 8 , the relationship becomes non-significant $(b=0.118)$. These results are also largely supported by the replication models ${ }^{7}$ (Table 5b in the Appendix), although we should be cautious with this interpretation as standard errors are large. The correlation between the relative resources variables and gender values was tested and never exceeded $9 \%$ for any indicator.

In summary, education does not capture the variance explained by egalitarian values on housework division, but this variance is captured by labour market variables. Education, income and gender values seem to affect housework through different mechanisms. However, the effects of gender values and labour market participation overlap to some extent. This appears to be the result of women who participate in the labour market being more likely to believe that housework should be equally shared between partners. In any

5. Housework shares are coded as deciles instead of percentiles.

6. Full results are available upon request.

7. The only discrepancy observed is when only income-related variables are included. In this case, the replication models showed that non-egalitarian values are significantly related to housework, while the main models show that they are not (models available upon request). 
case, I cannot resolve whether labour market participation triggers egalitarian values or if women with traditional values opt for being housewives. However, I explore if egalitarian values might influence housework division in dual-breadwinner couples. In this sub-sample I only analyse couples where both partners are working either part time or full time. In Model 9 the sample has been reduced to 3688 couples while controlling for egalitarian values in a basic model. The association is not significant $(b=0.103)$, showing no influence of egalitarian values on housework division. In addition, it is important to consider that two other statements that reflected gender-egalitarian beliefs were previously tested and showed no association with housework performance (results in Appendix in Table 4).

At this point, Hypothesis 1 is largely rejected; the only evidence of specialization due to educational differences is found for hypergamous men with medium education. Solely differences in the amount of work reflect economic rational strategies, probably derived from time constraints, although men do not increase their domestic work when they are unemployed, while women do. In contrast, Hypothesis 2 can be mostly accepted. The results indicate that men increase their housework dedication until the point where their earnings are surpassed by women's, after which it remains constant. Employment differences also indicate that women do more housework when they work less than men, but there is no reduction when men are unemployed. Both results can be interpreted as gender display. Regarding educational differences, there is no sign of possible gender deviance neutralization, but apparent signs of gender display: there is no decrease when highly or medium educated women partner with low educated men. In contrast, highly educated homogamous couples and (probably) women with secondary education whose husbands are highly educated do show a significant and negative relationship. These results could all be interpreted as the influence of men's education on their gender egalitarian attitudes, although this model cannot account for that. Instead, what seems to be reducing the housework of highly educated women partnered with medium educated men is education, as would be predicted by relative resources, with no influence of gender ideology. In the complete model (Model 4), gender egalitarian attitudes show a non-significant relationship, while the category "Women university, men upper secondary" remains significant. Moreover, Model 8 revealed that when simply accounting for labour market participation in a basic model, egalitarian values have no effect. When dual-earner couples are analysed, no association of egalitarian values with housework is observed (Model 9). In consequence, no support is found for Hypothesis 3, although limitations must be considered.

Two results probably reflect gender display. First, the fact that having paid help is related to less housework for women. From a rational perspective, this factor should not be significant once accounting for confounders. Instead, analyses indicate that having paid help significantly reduces the burden of housework for women. Second, the effect of kids is always related to more housework for women, even in the case of school-aged children. 


\section{Conclusion}

In this paper, I studied the division of domestic work between partners looking at relative resources, women's gender-egalitarian attitudes and, especially, educational differences in detail as determinants. I contrasted the two main theoretical frameworks that tackled the unequal division of unpaid work between partners: on the one hand, Becker's human capital differences and the relative resources approach; on the other, the doing gender perspective. My results show very limited support for theories of specialization, and wide support for doing gender. However, in the face of considerable methodological limitations, there is no support for the relationship between egalitarian beliefs and egalitarian behaviours.

In short, on average, women in Spain continue to do most of the housework. In line with gendered theories and previous studies (Sevilla-Sanz et al., 2010), I found that men's housework dedication increases until women earn the same as them and remains constant after that point. Similarly, women perform more domestic work when they are unemployed, but the equivalent is not found for men. Results consistent with the rational allocation perspectives reflect that women tend to reduce their housework dedication when they work more than men.

The consequences of educational asymmetries between partners on housework division are generally diverse, but irrelevant in terms of explanatory power. Regression models explain a slight percentage of variance, in line with other studies in the field. The results reveal that in most cases women will not do less housework if they partner with less educated men. Namely, reductions in housework were found exclusively among women with university education, both homogamous and hypogamous (and, perhaps, hypogamous men too). Nevertheless, when educational heterogamy is at its highest point (higher versus basic education), no difference in housework division is observed for men or women. Answering my introductory questions, I conclude that women only carry out fewer household chores if they attain a university education and partner with men with university or upper secondary education. There is no variation in housework division if women are not educated to university level, nor if their partners completed less than upper secondary education or vocational training. These results seem to be consistent with the findings of Van Berkel and De Graaf (1999), who indicated that when there is a big difference in educational attainment, the education of the wife has no effect. This could also be interpreted as the result of low educated men being less egalitarian. Education, then, can be considered an "equalizer" (although not great) when acknowledging that higher education increases men's contribution and reduces that of women. The fact that highly educated homogamous women, ceteris paribus, do less housework than medium educated homogamous women, while homogamous women with low education do as much housework as medium educated women, could be explained by more egalitarian attitudes among highly educated men. These results highlight that analyses can be richer if 
we look at different couple's educational compositions instead of considering education as linear and independent between partners. The association is not linear: only college education appears to affect housework division, but not if the other partner is low educated.

Although gendered approaches provide an accurate framework for understanding housework division, women's gender-egalitarian beliefs are not significantly related to housework performance. Testing the effect of the belief in the equal division of housework was my closest but still partial approximation to Esping-Andersen et al.'s (2013) question ("Are couples more likely to embrace greater gender symmetry because of equity tensions or in the interest of more efficient outcomes?"). My conclusion is that, if the chosen statement ("men should participate in housework as much as women") can be considered a good indicator of potential "equity tensions", couples are not more likely to embrace gender symmetry because of this factor. However, besides the possible inadequacy of the indicator, there are two more relevant reasons why my findings might be incorrect: First, because of using a reported indicator based on estimations, being a worker instead of a housewife, or being the main earner, may distort the perception of housework. Even the lack of significance of gender-egalitarian attitudes could be explained by within-group variations. Some evidence suggests that traditional women tend to overestimate their housework performance, whereas non-traditional women tend to "overestimate less" (Press and Townsley, 1998). Yet some egalitarian women could be reporting higher housework shares since they have a greater awareness of their over-performance than traditional women. Others may be adapting or reproducing their expectations and desires of fairness once equality was seen as unachievable (Kamo, 2000). Second, I did not study the possible influence of men's gender egalitarian attitudes. Greenstein (1996) has highlighted the relevance of the interaction effects in order to explain how partner's attitudes are translated into less female housework. Could greater housework equity among highly educated homogamous couples be the result of men's gender-egalitarian attitudes, as Shelton and John (1996) suggested? Although the evidence proved to be somewhat mixed in this regard, my analyses suggest that when simply controlling for job-related variables, women's egalitarian beliefs have no effect on housework division. In any case, this hypothesis could be better tested with the men's sample of the Fertility Survey.

To the best of my knowledge, this study is the first in Spain, at least in the last decades, that tests the effects of gender ideology with a direct indicator, and the first to look at the composition of couples, observing interactions between the level of education of the partners. Since the 2018 Fertility Survey seems to be the first one collecting housework division as a reported percentage, this study is the first one analysing this kind of variable. Hence, limitations must be stressed, and my conclusions and findings should thus be interpreted as a point of departure for future analyses that can make use of more reliable indicators. First, the biggest problem is obtaining the dependent variable. Even though women and men appear to report very similar indicators of domestic work, 
using an estimated indicator is not wholly accurate. Associations could be simply explaining "perceived housework" instead of real housework, while gender differences in the types of tasks performed could influence their perception of what their partners do (Van Berkel and De Graaf, 1999). Similarly, couple-level variables are not reported by men themselves. Third, the categorization of household and individual income is ordinal instead of continuous, and the intervals are not even, which can also bias my estimators and the classification of income shares.

As usual, further research is needed to provide updated indicators of the division of domestic work after a period where economic constraints may have broken some gender norms within couples. In this regard, time use surveys offer the most reliable information, and further research could be oriented towards accurately measuring the effects of relative resources and educational differences. Future studies using the Fertility Survey could explore how parents' work division may influence women's and men's behaviour, something missing in this paper. With regard to gender-egalitarian values, further analyses could explore their determinants; in particular, whether the participation of women in the labour market might trigger more egalitarian attitudes towards housework than educational attainment does. Finally, whether medium educated women reduce their housework when partnered with highly educated men should be explored in greater depth. In this regard, the results remain tentative given the low level of statistical significance. 


\section{Appendix}

Table 4. Estimates of OLS regression models: Effects different estimators of gender-egalitarian attitudes on women's housework shares

\begin{tabular}{|c|c|c|c|}
\hline & $\begin{array}{c}\text { Model } 1 \\
\text { b/(se) }\end{array}$ & $\begin{array}{c}\text { Model } 2 \\
\text { b/(se) }\end{array}$ & $\begin{array}{c}\text { Model } 3 \\
\text { b/(se) }\end{array}$ \\
\hline \multicolumn{4}{|l|}{ Paid help (ref. $=$ no) } \\
\hline Yes & $\begin{array}{l}-0.339^{\star \star \star} \\
(0.07)\end{array}$ & $\begin{array}{l}-0.342^{\star \star \star} \\
(0.07)\end{array}$ & $\begin{array}{l}-0.342^{\star \star \star} \\
(0.07)\end{array}$ \\
\hline \multicolumn{4}{|l|}{ Demographic variables } \\
\hline Number of kids $(0-3)$ & $\begin{array}{l}0.212^{\star \star \star} \\
(0.05)\end{array}$ & $\begin{array}{l}0.212^{\star \star \star} \\
(0.05)\end{array}$ & $\begin{array}{l}0.212^{\star \star \star} \\
(0.05)\end{array}$ \\
\hline Number of kids (4-9) & $\begin{array}{l}0.189^{\star \star \star} \\
(0.04)\end{array}$ & $\begin{array}{l}0.194^{\star \star \star} \\
(0.04)\end{array}$ & $\begin{array}{l}0.194^{\star \star \star} \\
(0.04)\end{array}$ \\
\hline Number of kids $(10+)$ & $\begin{array}{l}0.161^{\star \star \star} \\
(0.03)\end{array}$ & $\begin{array}{l}0.163^{\star \star \star} \\
(0.03)\end{array}$ & $\begin{array}{l}0.163^{\star \star \star} \\
(0.03)\end{array}$ \\
\hline \multicolumn{4}{|c|}{ Women immigrant status (Ref.=native) } \\
\hline Long term resident & $\begin{array}{l}0.032 \\
(0.12)\end{array}$ & $\begin{array}{l}0.040 \\
(0.12)\end{array}$ & $\begin{array}{l}0.041 \\
(0.12)\end{array}$ \\
\hline Short-term resident & $\begin{array}{l}0.152 \\
(0.12)\end{array}$ & $\begin{array}{l}0.166 \\
(0.12)\end{array}$ & $\begin{array}{l}0.166 \\
(0.12)\end{array}$ \\
\hline \multicolumn{4}{|c|}{ Men immigrant status (Ref.=native) } \\
\hline Long term resident & $\begin{array}{r}-0.134 \\
(0.12)\end{array}$ & $\begin{array}{r}-0.131 \\
(0.12)\end{array}$ & $\begin{array}{r}-0.131 \\
(0.12)\end{array}$ \\
\hline Short-term resident & $\begin{array}{c}-0.239\left(^{*}\right) \\
(0.14)\end{array}$ & $\begin{array}{r}-0.237 \\
(0.14)\end{array}$ & $\begin{array}{c}-0.236\left(^{*}\right) \\
(0.14)\end{array}$ \\
\hline Years cohabiting & $\begin{array}{l}0.017^{\star \star \star} \\
(0.00)\end{array}$ & $\begin{array}{l}0.017^{\star \star \star} \\
(0.00)\end{array}$ & $\begin{array}{l}0.017^{\star \star \star} \\
(0.00)\end{array}$ \\
\hline Women's age & $\begin{array}{c}0.005 \\
(0.01)\end{array}$ & $\begin{array}{l}0.005 \\
(0.01)\end{array}$ & $\begin{array}{c}0.005 \\
(0.01)\end{array}$ \\
\hline Age difference & $\begin{array}{c}0.001 \\
(0.01)\end{array}$ & $\begin{array}{c}0.001 \\
(0.01)\end{array}$ & $\begin{array}{c}0.001 \\
(0.01)\end{array}$ \\
\hline \multicolumn{4}{|c|}{ Women's student status (Ref.=Yes) } \\
\hline No & $\begin{array}{l}-0.052 \\
(0.08)\end{array}$ & $\begin{array}{l}-0.046 \\
(0.08)\end{array}$ & $\begin{array}{l}-0.046 \\
(0.08)\end{array}$ \\
\hline \multicolumn{4}{|c|}{ Pregnancy status (Ref.=not pregnant) } \\
\hline Yes & $\begin{array}{c}-0.086 \\
(0.11)\end{array}$ & $\begin{array}{c}-0.082 \\
(0.11)\end{array}$ & $\begin{array}{c}-0.081 \\
(0.11)\end{array}$ \\
\hline \multicolumn{4}{|c|}{ Relative resources } \\
\hline \multicolumn{4}{|c|}{ Relative education (Ref. = Both Upper Secondary/Vocational Training) } \\
\hline Both low & $\begin{array}{l}0.106 \\
(0.08)\end{array}$ & $\begin{array}{l}0.122 \\
(0.08)\end{array}$ & $\begin{array}{l}0.123 \\
(0.08)\end{array}$ \\
\hline Women up. sec., men low & $\begin{array}{l}0.091 \\
(0.08)\end{array}$ & $\begin{array}{l}0.087 \\
(0.08)\end{array}$ & $\begin{array}{l}0.087 \\
(0.08)\end{array}$ \\
\hline
\end{tabular}


Table 4. Estimates of OLS regression models: Effects different estimators of gender-egalitarian attitudes on women's housework shares (continued)

\begin{tabular}{lccc}
\hline & $\begin{array}{c}\text { Model 1 } \\
\mathrm{b} /(\mathrm{se})\end{array}$ & $\begin{array}{c}\text { Model 2 } \\
\mathrm{b} /(\mathrm{se})\end{array}$ & $\begin{array}{c}\text { Model 3 } \\
\mathrm{b} /(\mathrm{se})\end{array}$ \\
\hline Women university, men low & 0.096 & 0.087 & 0.087 \\
& $(0.12)$ & $(0.12)$ & $(0.12)$ \\
Men up. sec., women low & 0.038 & 0.040 & 0.040 \\
Women university, men up. sec. & $(0.11)$ & $(0.11)$ & $(0.11)$ \\
& $-0.431^{\star \star \star}$ & $-0.436^{\star \star \star}$ & $-0.435^{\star \star \star}$ \\
Men university, women low & $(0.08)$ & $(0.08)$ & $(0.08)$ \\
Men university, women up. sec. & 0.308 & 0.309 & 0.310 \\
& $(0.19)$ & $(0.19)$ & $(0.19)$ \\
Both university & -0.080 & -0.083 & -0.082 \\
& $(0.09)$ & $(0.09)$ & $(0.09)$ \\
\hline Gender attitudes & $-0.413^{\star \star \star}$ & $-0.419^{\star \star \star}$ & $-0.419^{\star \star \star}$ \\
Housework fairness (Ref.= egalitarian) & $(0.07)$ & $(0.07)$ & $(0.07)$ \\
Non-egalitarian & & & \\
Earning differences (Ref.= egalitarian) & & & \\
Non-egalitarian & $0.248^{\star \star}$ & & \\
Jobs priority (Ref.= egalitarian) & $(0.09)$ & & \\
Non-egalitarian & & & \\
Intercept & & -0.014 & \\
\hline R2 & & & \\
N & & & \\
\hline
\end{tabular}

Note: $\left({ }^{\star}\right) p<0.10,{ }^{*} p<0.05,{ }^{\star \star} p<0.01,{ }^{\star \star \star} p<0.001$. Weights provided by the survey and heteroskedasticity-robust indicators have been used in the analysis.

(1) Statement: "Men should participate in housework as much as women".

(2) Statement: "If the woman earns more than her partner, that is not good for the relationship".

(3) Statement: "When jobs are scarce, men should have more right to a job than women".

Source: Own elaboration using the Fertility Survey (Spain) of 2018, INE. 
Table 5a. Estimates of OLS Regression models: Replication of Table 3a using a different estimator. Effects on women's housework shares

\begin{tabular}{|c|c|c|c|c|}
\hline & $\begin{array}{c}\text { Model } 1 \\
\text { b/(se) }\end{array}$ & $\begin{array}{c}\text { Model } 2 \\
\text { b/(se) }\end{array}$ & $\begin{array}{c}\text { Model } 3 \\
\text { b/(se) }\end{array}$ & $\begin{array}{c}\text { Model } 4 \\
\text { b/(se) }\end{array}$ \\
\hline \multicolumn{5}{|l|}{ Paid help (ref. $=$ No) } \\
\hline Yes & $\begin{array}{l}0.095 \\
(0.08)\end{array}$ & $\begin{array}{l}0.170^{*} \\
(0.08)\end{array}$ & $\begin{array}{l}0.261^{\star \star} \\
(0.08)\end{array}$ & $\begin{array}{l}0.262^{\text {** }} \\
(0.08)\end{array}$ \\
\hline \multicolumn{5}{|l|}{ Demographic variables } \\
\hline Number of kids (0-3) & $\begin{array}{l}0.204^{\star \star \star} \\
(0.05)\end{array}$ & $\begin{array}{l}0.150^{\star \star} \\
(0.05)\end{array}$ & $\begin{array}{l}0.112^{\star} \\
(0.05)\end{array}$ & $\begin{array}{l}0.113^{*} \\
(0.05)\end{array}$ \\
\hline Number of kids (4-9) & $\begin{array}{l}0.192^{\star \star \star} \\
(0.04)\end{array}$ & $\begin{array}{l}0.146^{\star \star \star} \\
(0.04)\end{array}$ & $\begin{array}{l}0.120^{\star *} \\
(0.04)\end{array}$ & $\begin{array}{l}0.118^{\star \star} \\
(0.04)\end{array}$ \\
\hline Number of kids $(10+)$ & $\begin{array}{l}0.237^{\star \star \star} \\
(0.03)\end{array}$ & $\begin{array}{l}0.184^{\star \star \star} \\
(0.03)\end{array}$ & $\begin{array}{l}0.177^{\star \star \star} \\
(0.03)\end{array}$ & $\begin{array}{l}0.177^{\star \star \star} \\
(0.03)\end{array}$ \\
\hline \multicolumn{5}{|c|}{ Women immigrant status (Ref.=Native) } \\
\hline Long term resident & $\begin{array}{c}0.124 \\
(0.14)\end{array}$ & $\begin{array}{l}0.110 \\
(0.13)\end{array}$ & $\begin{array}{l}0.089 \\
(0.13)\end{array}$ & $\begin{array}{l}0.085 \\
(0.13)\end{array}$ \\
\hline Short-term resident & $\begin{array}{l}0.222\left(^{*}\right) \\
(0.13)\end{array}$ & $\begin{array}{l}0.050 \\
(0.13)\end{array}$ & $\begin{array}{l}0.021 \\
(0.12)\end{array}$ & $\begin{array}{l}0.016 \\
(0.12)\end{array}$ \\
\hline \multicolumn{5}{|c|}{ Men immigrant status (Ref.=Native) } \\
\hline Long term resident & $\begin{array}{c}-0.145 \\
(0.13)\end{array}$ & $\begin{array}{c}-0.129 \\
(0.13)\end{array}$ & $\begin{array}{c}-0.087 \\
(0.13)\end{array}$ & $\begin{array}{c}-0.088 \\
(0.13)\end{array}$ \\
\hline Short-term resident & $\begin{array}{c}-0.206 \\
(0.15)\end{array}$ & $\begin{array}{c}-0.145 \\
(0.14)\end{array}$ & $\begin{array}{c}-0.164 \\
(0.14)\end{array}$ & $\begin{array}{c}-0.166 \\
(0.14)\end{array}$ \\
\hline Years cohabiting & $\begin{array}{l}0.021^{\star * \star} \\
(0.01)\end{array}$ & $\begin{array}{l}0.018^{\star \star \star} \\
(0.01)\end{array}$ & $\begin{array}{l}0.017^{\star \star} \\
(0.01)\end{array}$ & $\begin{array}{l}0.017^{\star \star} \\
(0.01)\end{array}$ \\
\hline Women's age & $\begin{array}{l}0.008 \\
(0.01)\end{array}$ & $\begin{array}{l}0.008 \\
(0.01)\end{array}$ & $\begin{array}{l}0.012\left(^{*}\right) \\
(0.01)\end{array}$ & $\begin{array}{l}0.011\left(^{*}\right) \\
(0.01)\end{array}$ \\
\hline Age difference & $\begin{array}{c}0.003 \\
(0.01)\end{array}$ & $\begin{array}{l}-0.001 \\
(0.01)\end{array}$ & $\begin{array}{l}-0.000 \\
(0.01)\end{array}$ & $\begin{array}{l}-0.000 \\
(0.01)\end{array}$ \\
\hline \multicolumn{5}{|c|}{ Women's student status (Ref.=Yes) } \\
\hline No & $\begin{array}{c}-0.053 \\
(0.08)\end{array}$ & $\begin{array}{c}-0.026 \\
(0.08)\end{array}$ & $\begin{array}{l}0.022 \\
(0.08)\end{array}$ & $\begin{array}{l}0.019 \\
(0.08)\end{array}$ \\
\hline \multicolumn{5}{|c|}{ Pregnancy (Ref.=Not pregnant) } \\
\hline Yes & $\begin{array}{c}-0.052 \\
(0.12)\end{array}$ & $\begin{array}{c}-0.141 \\
(0.12)\end{array}$ & $\begin{array}{c}-0.100 \\
(0.12)\end{array}$ & $\begin{array}{c}-0.102 \\
(0.13)\end{array}$ \\
\hline
\end{tabular}

Relative resources

Relative education (Ref. $=$ Both Upper Secondary/Vocational Training)

$\begin{array}{lcccc}\text { Both low } & 0.198^{*} & 0.043 & 0.018 & 0.011 \\ \text { Women up. sec., men low } & (0.09) & (0.09) & (0.09) & (0.09) \\ & 0.137 & 0.152 & 0.127 & 0.128 \\ \text { Women university, men low } & (0.09) & (0.09) & (0.08) & (0.08) \\ \text { Men up. sec., women low } & 0.130 & 0.241\left(^{*}\right) & 0.207 & 0.211 \\ & (0.13) & (0.13) & (0.13) & (0.13) \\ \text { Women university, men up. sec. } & 0.069 & -0.049 & -0.079 & -0.079 \\ & (0.12) & (0.11) & (0.11) & (0.11) \\ & -0.468^{\star \star *} & -0.374^{\star \star *} & -0.346^{\star \star *} & -0.345^{\star \star \star} \\ & (0.08) & (0.08) & (0.08) & (0.08)\end{array}$


Table 5a. Estimates of OLS Regression models: Replication of Table 3a using a different estimator. Effects on women's housework shares (continued)

\begin{tabular}{|c|c|c|c|c|}
\hline & $\begin{array}{c}\text { Model } 1 \\
\text { b/(se) }\end{array}$ & $\begin{array}{c}\text { Model } 2 \\
\text { b/(se) }\end{array}$ & $\begin{array}{c}\text { Model } 3 \\
\text { b/(se) }\end{array}$ & $\begin{array}{c}\text { Model } 4 \\
\text { b/(se) }\end{array}$ \\
\hline Men university, women low & $\begin{array}{c}0.254 \\
(0.21)\end{array}$ & $\begin{array}{c}0.010 \\
(0.20)\end{array}$ & $\begin{array}{c}-0.037 \\
(0.19)\end{array}$ & $\begin{array}{l}-0.036 \\
(0.19)\end{array}$ \\
\hline Men university, women up. sec. & $\begin{array}{c}-0.063 \\
(0.10)\end{array}$ & $\begin{array}{c}-0.185 \\
(0.10)\end{array}$ & $\begin{array}{c}-0.148 \\
(0.10)\end{array}$ & $\begin{array}{c}-0.146 \\
(0.10)\end{array}$ \\
\hline Both university & $\begin{array}{l}-0.445^{\star \star \star} \\
(0.07)\end{array}$ & $\begin{array}{l}-0.383^{\star \star \star} \\
(0.07)\end{array}$ & $\begin{array}{l}-0.312^{\star \star \star} \\
(0.07)\end{array}$ & $\begin{array}{l}-0.309^{\star \star \star} \\
(0.08)\end{array}$ \\
\hline \multicolumn{5}{|c|}{ Women's relative income (Ref.= Both between 40-59\%) } \\
\hline $0-19 \%$ & & $\begin{array}{l}0.965^{\star \star \star} \\
(0.07)\end{array}$ & $\begin{array}{l}0.367^{\star \star \star} \\
(0.09)\end{array}$ & $\begin{array}{l}0.364^{\star \star \star} \\
(0.09)\end{array}$ \\
\hline $20-39 \%$ & & 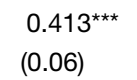 & $\begin{array}{l}0.182^{\star *} \\
(0.07)\end{array}$ & $\begin{array}{l}0.178^{\star \star} \\
(0.07)\end{array}$ \\
\hline $60-79 \%$ & & $\begin{array}{l}-0.123 \\
(0.09)\end{array}$ & $\begin{array}{c}0.023 \\
(0.10)\end{array}$ & $\begin{array}{l}0.021 \\
(0.10)\end{array}$ \\
\hline $80-100 \%$ & & $\begin{array}{l}-0.576^{\star \star \star} \\
(0.17)\end{array}$ & $\begin{array}{l}-0.157 \\
(0.18)\end{array}$ & $\begin{array}{r}-0.161 \\
(0.18)\end{array}$ \\
\hline Household income & & & $\begin{array}{l}-0.000 \\
(0.02)\end{array}$ & $\begin{array}{r}-0.001 \\
(0.02)\end{array}$ \\
\hline Women's seniority & & & $\begin{array}{l}-0.007 \\
(0.00)\end{array}$ & $\begin{array}{c}-0.007\left(^{*}\right) \\
(0.00)\end{array}$ \\
\hline \multicolumn{5}{|c|}{ Relative work shifts (Ref. = Both equal) } \\
\hline Men more than women & & & $\begin{array}{l}0.431^{\star \star \star} \\
(0.08)\end{array}$ & $\begin{array}{l}0.431^{\star \star \star} \\
(0.08)\end{array}$ \\
\hline Women more than men & & & $\begin{array}{c}-0.284 \\
(0.16)\end{array}$ & $\begin{array}{c}-0.283\left(^{*}\right) \\
(0.16)\end{array}$ \\
\hline \multicolumn{5}{|l|}{ Men's job sector (Ref.=Public) } \\
\hline Unemployed & & & $\begin{array}{c}-0.186 \\
(0.23)\end{array}$ & $\begin{array}{c}-0.182 \\
(0.23)\end{array}$ \\
\hline Private & & & $\begin{array}{l}0.223^{\star \star \star} \\
(0.06)\end{array}$ & $\begin{array}{l}0.222^{\star \star \star} \\
(0.06)\end{array}$ \\
\hline \multicolumn{5}{|l|}{ Women's job sector (Ref.=Public) } \\
\hline Unemployed & & & $\begin{array}{l}0.237 \\
(0.12)\end{array}$ & $\begin{array}{l}0.230\left({ }^{*}\right) \\
(0.12)\end{array}$ \\
\hline Private & & & $\begin{array}{l}-0.069 \\
(0.06)\end{array}$ & $\begin{array}{r}-0.071 \\
(0.06) \\
\end{array}$ \\
\hline \multicolumn{5}{|l|}{ Gender attitudes } \\
\hline \multicolumn{5}{|c|}{ Housework fairness (Ref.= Egalitarian) } \\
\hline Non-egalitarian & & & & $\begin{array}{l}0.141 \\
(0.10)\end{array}$ \\
\hline Intercept & $\begin{array}{l}6.083^{\star \star \star} \\
(0.22) \\
\end{array}$ & $\begin{array}{l}5.970^{\star \star \star} \\
(0.22) \\
\end{array}$ & $\begin{array}{l}5.635^{\star \star \star} \\
(0.24)\end{array}$ & $\begin{array}{l}5.637^{\star \star \star} \\
(0.24)\end{array}$ \\
\hline R2 & 0.070 & 0.120 & 0.148 & 0.148 \\
\hline $\mathrm{N}$ & 7031 & 7031 & 7031 & 7031 \\
\hline
\end{tabular}

Note: ( $\left.{ }^{*}\right) p<0.10,{ }^{*} p<0.05,{ }^{* *} p<0.01,{ }^{* * *} p<0.001$. Weights provided by the survey and heteroskedasticity-robust indicators have been used in the analysis.

Source: Own elaboration using the Fertility Survey (Spain) of 2018, INE. 
Table 6b. Estimates of OLS Regression models: Replication of Table 3b using a different estimator. Effects on women's housework shares

\begin{tabular}{|c|c|c|c|c|c|}
\hline & $\begin{array}{c}\text { Model } 5 \\
\text { b/(se) }\end{array}$ & $\begin{array}{c}\text { Model } 6 \\
\text { b/(se) }\end{array}$ & $\begin{array}{c}\text { Model } 7 \\
\text { b/(se) }\end{array}$ & $\begin{array}{c}\text { Model } 8 \\
\text { b/(se) }\end{array}$ & $\begin{array}{c}\text { Model } 9^{1} \\
\text { b/(se) }\end{array}$ \\
\hline \multicolumn{6}{|l|}{ Paid help (ref. $=$ No) } \\
\hline Yes & $\begin{array}{l}0.098 \\
(0.08)\end{array}$ & $\begin{array}{l}0.177^{\star} \\
(0.08)\end{array}$ & $\begin{array}{l}0.143\left({ }^{*}\right) \\
(0.08)\end{array}$ & $\begin{array}{l}0.221^{\star \star} \\
(0.08)\end{array}$ & $\begin{array}{l}0.099 \\
(0.09)\end{array}$ \\
\hline \multicolumn{6}{|l|}{ Demographic variables } \\
\hline Number of kids $(0-3)$ & $\begin{array}{l}0.204^{\star \star *} \\
(0.05)\end{array}$ & $\begin{array}{l}0.150^{\star *} \\
(0.05)\end{array}$ & $\begin{array}{l}0.093\left({ }^{*}\right) \\
(0.05)\end{array}$ & $\begin{array}{l}0.120^{*} \\
(0.05)\end{array}$ & $\begin{array}{l}0.197^{\star *} \\
(0.07)\end{array}$ \\
\hline Number of kids (4-9) & $\begin{array}{l}0.186^{\star \star \star} \\
(0.04)\end{array}$ & $\begin{array}{l}0.143^{\star \star \star} \\
(0.04)\end{array}$ & $\begin{array}{l}0.112^{\star \star} \\
(0.04)\end{array}$ & $\begin{array}{l}0.134^{\star \star \star} \\
(0.04)\end{array}$ & $\begin{array}{l}0.204^{\star \star \star} \\
(0.05)\end{array}$ \\
\hline Number of kids (10+) & $\begin{array}{l}0.234^{\star \star \star} \\
(0.03)\end{array}$ & $\begin{array}{l}0.183^{\star \star \star} \\
(0.03)\end{array}$ & $\begin{array}{l}0.186^{\star \star \star} \\
(0.03)\end{array}$ & $\begin{array}{l}0.191^{\star \star \star} \\
(0.03)\end{array}$ & $\begin{array}{l}0.208^{\star \star \star} \\
(0.04)\end{array}$ \\
\hline \multicolumn{6}{|c|}{ Women immigrant status (Ref.=Native) } \\
\hline Long term resident & $\begin{array}{l}0.115 \\
(0.14)\end{array}$ & $\begin{array}{l}0.103 \\
(0.13)\end{array}$ & $\begin{array}{c}0.097 \\
(0.13)\end{array}$ & $\begin{array}{l}0.096 \\
(0.13)\end{array}$ & $\begin{array}{c}0.222 \\
(0.183)\end{array}$ \\
\hline Short-term resident & $\begin{array}{l}0.208 \\
(0.13)\end{array}$ & $\begin{array}{l}0.039 \\
(0.13)\end{array}$ & $\begin{array}{c}0.014 \\
(0.12)\end{array}$ & $\begin{array}{l}0.094 \\
(0.13)\end{array}$ & $\begin{array}{l}-0.064 \\
(0.18)\end{array}$ \\
\hline \multicolumn{6}{|c|}{ Men immigrant status (Ref.=Native) } \\
\hline Long term resident & $\begin{array}{l}-0.147 \\
(0.13)\end{array}$ & $\begin{array}{l}-0.132 \\
(0.13)\end{array}$ & $\begin{array}{l}-0.071 \\
(0.13)\end{array}$ & $\begin{array}{l}-0.089 \\
(0.13)\end{array}$ & $\begin{array}{l}-0.244 \\
(0.18)\end{array}$ \\
\hline Short-term resident & $\begin{array}{l}-0.209 \\
(0.15)\end{array}$ & $\begin{array}{c}-0.147 \\
(0.14)\end{array}$ & $\begin{array}{c}-0.176 \\
(0.14)\end{array}$ & $\begin{array}{l}-0.190 \\
(0.14)\end{array}$ & $\begin{array}{c}-0.291 \\
(0.20)\end{array}$ \\
\hline Years cohabiting & $\begin{array}{l}0.021^{\star * \star} \\
(0.01)\end{array}$ & $\begin{array}{l}0.018^{* * \star} \\
(0.01)\end{array}$ & $\begin{array}{l}0.023^{\star \star \star} \\
(0.01)\end{array}$ & $\begin{array}{l}0.018^{\star \star \star} \\
(0.01)\end{array}$ & $\begin{array}{l}0.024^{\star \star *} \\
(0.01)\end{array}$ \\
\hline Women's age & $\begin{array}{l}0.007 \\
(0.01)\end{array}$ & $\begin{array}{l}0.008 \\
(0.01)\end{array}$ & $\begin{array}{l}0.009 \\
(0.01)\end{array}$ & $\begin{array}{l}0.009 \\
(0.01)\end{array}$ & $\begin{array}{l}0.001 \\
(0.01)\end{array}$ \\
\hline Age difference & $\begin{array}{l}0.003 \\
(0.01)\end{array}$ & $\begin{array}{l}-0.001 \\
(0.01)\end{array}$ & $\begin{array}{c}0.001 \\
(0.01)\end{array}$ & $\begin{array}{l}-0.001 \\
(0.01)\end{array}$ & $\begin{array}{l}0.003 \\
(0.01)\end{array}$ \\
\hline \multicolumn{6}{|c|}{ Women's student status (Ref.=Yes) } \\
\hline No & $\begin{array}{l}-0.059 \\
(0.08)\end{array}$ & $\begin{array}{l}-0.030 \\
(0.08)\end{array}$ & $\begin{array}{l}0.085 \\
(0.08)\end{array}$ & $\begin{array}{l}0.006 \\
(0.08)\end{array}$ & $\begin{array}{l}0.065 \\
(0.11)\end{array}$ \\
\hline \multicolumn{6}{|c|}{ Pregnancy (Ref.=Not pregnant) } \\
\hline Yes & $\begin{array}{l}-0.057 \\
(0.12)\end{array}$ & $\begin{array}{l}-0.145 \\
(0.12)\end{array}$ & $\begin{array}{l}-0.074 \\
(0.12)\end{array}$ & $\begin{array}{l}-0.093 \\
(0.13)\end{array}$ & $\begin{array}{l}0.083 \\
(0.15)\end{array}$ \\
\hline
\end{tabular}

\section{Relative resources}

Relative education (Ref. $=$ Both Upper Secondary/Vocational Training)

Both low

$\begin{array}{lll}0.180^{\star} & 0.028 & 0.026 \\ (0.09) & (0.09) & (0.09) \\ 0.141 & 0.153\left(^{\star}\right) & 0.127 \\ (0.09) & (0.09) & (0.09) \\ 0.139 & 0.249\left(^{\star}\right) & 0.191 \\ (0.13) & (0.13) & (0.13) \\ 0.067 & -0.051 & -0.046 \\ (0.12) & (0.11) & (0.11) \\ -0.464^{\star \star \star} & -0.367^{\star \star \star} & -0.368^{\star \star \star} \\ (0.08) & (0.08) & (0.08)\end{array}$

Women up. sec., men low

Women university, men low

Men up. sec., women low

$0.067-0.051$

Men up. sec., women low

Women university, men up. sec.

$\begin{array}{ll}-0.464^{\star \star \star} & -0.367^{\star \star \star} \\ (0.08) & (0.08)\end{array}$

(0.08) 
Table 6b. Estimates of OLS Regression models: Replication of Table 3b using a different estimator. Effects on women's housework shares (continued)

\begin{tabular}{|c|c|c|c|c|c|}
\hline & $\begin{array}{c}\text { Model } 5 \\
\text { b/(se) }\end{array}$ & $\begin{array}{c}\text { Model } 6 \\
\text { b/(se) }\end{array}$ & $\begin{array}{c}\text { Model } 7 \\
\text { b/(se) }\end{array}$ & $\begin{array}{c}\text { Model } 8 \\
\text { b/(se) }\end{array}$ & $\begin{array}{c}\text { Model } 9^{1} \\
\text { b/(se) }\end{array}$ \\
\hline \multirow[t]{2}{*}{ Men university, women low } & 0.253 & 0.012 & & 0.012 & \\
\hline & $(0.21)$ & $(0.20)$ & & $(0.20)$ & \\
\hline \multirow[t]{2}{*}{ Men university, women up. sec. } & -0.061 & $-0.178\left(^{*}\right)$ & & -0.111 & \\
\hline & $(0.10)$ & $(0.10)$ & & $(0.10)$ & \\
\hline \multirow[t]{2}{*}{ Both university } & $-0.439^{\star \star \star}$ & $-0.372^{\star \star \star}$ & & $-0.321^{\star \star \star}$ & \\
\hline & $(0.07)$ & $(0.08)$ & & $(0.07)$ & \\
\hline \multicolumn{6}{|c|}{ Women's relative income (Ref.= Both between $40-59 \%)$} \\
\hline \multirow[t]{2}{*}{$0-19 \%$} & & $0.947^{\star \star \star}$ & & & \\
\hline & & $(0.07)$ & & & \\
\hline \multirow[t]{2}{*}{$20-39 \%$} & & $0.404^{\star \star *}$ & & & \\
\hline & & $(0.07)$ & & & \\
\hline \multirow[t]{2}{*}{$60-79 \%$} & & -0.126 & & & \\
\hline & & $(0.09)$ & & & \\
\hline \multirow[t]{2}{*}{$80-100 \%$} & & $-0.583^{\star \star \star}$ & & & \\
\hline & & $(0.17)$ & & & \\
\hline \multirow[t]{2}{*}{ Household income } & & -0.006 & & & \\
\hline & & $(0.02)$ & & & \\
\hline \multirow[t]{2}{*}{ Women's seniority } & & & $-0.008^{\star}$ & & \\
\hline & & & $(0.00)$ & & \\
\hline \multicolumn{6}{|c|}{ Relative work shifts (Ref. = Both equal) } \\
\hline \multirow[t]{2}{*}{ Men more than women } & & & $0.514^{\star \star \star}$ & & \\
\hline & & & $(0.07)$ & & \\
\hline \multirow[t]{2}{*}{ Women more than men } & & & -0.259 & & \\
\hline & & & $(0.16)$ & & \\
\hline \multicolumn{6}{|l|}{ Men's job sector (Ref.=Public) } \\
\hline \multirow[t]{2}{*}{ Unemployed } & & & -0.228 & $-0.652^{\star \star \star}$ & \\
\hline & & & $(0.22)$ & $(0.16)$ & \\
\hline \multirow[t]{2}{*}{ Private } & & & $0.259^{\star \star \star}$ & $0.228^{\star \star \star}$ & \\
\hline & & & $(0.06)$ & $(0.06)$ & \\
\hline \multicolumn{6}{|l|}{ Women's job sector (Ref.=Public) } \\
\hline \multirow[t]{2}{*}{ Unemployed } & & & $0.475^{\star \star \star}$ & $0.936^{\star \star \star}$ & \\
\hline & & & $(0.10)$ & $(0.07)$ & \\
\hline \multirow[t]{2}{*}{ Private } & & & -0.011 & 0.023 & \\
\hline & & & $(0.06)$ & $(0.06)$ & \\
\hline
\end{tabular}

\begin{tabular}{llllll}
\hline $\begin{array}{l}\text { Gender attitudes } \\
\text { Housework fairness (Ref.= Egalitarian) }\end{array}$ & & & & & \\
$\quad$ Non-egalitarian & $0.296^{\star *}$ & $0.196^{*}$ & 0.155 & 0.156 & 0.945 \\
& $(0.10)$ & $(0.10)$ & $(0.10)$ & $(0.10)$ & $(0.13)$ \\
Intercept & $6.073^{\star \star *}$ & $5.991^{* \star *}$ & $5.466^{\star \star *}$ & $5.711^{* \star \star}$ & $5.835^{\star \star *}$ \\
& $(0.22)$ & $(0.23)$ & $(0.22)$ & $(0.23)$ & $(0.27)$ \\
\hline R2 & 0.072 & 0.121 & 0.137 & 0.134 & 0.044 \\
$\mathrm{~N}$ & 7031 & 7031 & 7031 & 7031 & 3688 \\
\hline
\end{tabular}

Note: $\left({ }^{*}\right) p<0.10,{ }^{*} p<0.05,{ }^{* \star} p<0.01,{ }^{* * \star} p<0.001$. Weights provided by the survey and heteroskedasticity-robust indicators have been used in the analysis.

(1) This model only includes dual-breadwinner couples.

Source: Own elaboration using the Fertility Survey (Spain) of 2018, INE. 


\section{Acknowledgements}

This article is part of a master's thesis undertaken in the Research Master in Sociology and Demography in Pompeu Fabra University in 2019. I would like to thank Gøsta Esping-Andersen, who supervised this thesis, and also María Luisa Barón Salas, Alessandro Di Nallo, Zahia Guidoum Castiblanque, Fabiana Macor, Jad Moawad and the anonymous reviewers, who provided valuable advice, insightful comments and made corrections that improved the overall quality of the article.

\section{Bibliographic references}

Aasve, Arnstein; Fouchi, Giulia and Mencarini, Letizia (2014). "Desperate Housework: Relative Resources, Time Availability, Economic Dependency, and Gender Ideology Across Europe". Journal of Family Issues, 35 (8), 1000-1022. $<$ https://doi.org/10.1177/0192513X14522248>

Álvarez, Begoña and Miles, Daniel J. (2003). "Gender Effect on Housework Allocation: Evidence from Spanish Two-earner Couples". Journal of Population Economics, 16 (2), 227-242. $<$ https://doi.org/10.1007/s001480200126>

Amuedo-Dorantes, Catalina and De la Rica, Sara (2006). "The Role of Segregation and Pay Structure on the Gender Wage Gap: Evidence from Matched Employer-Employee Data for Spain”. The B.E. Journal of Economic Analysis \& Policy, 5 (1). $<$ https://doi.org/10.2202/1538-0645.1498>

- (2009). The Timing of Work and Work-Family Conflicts in Spain: Who Has a Split Work Schedule and Why? Bonn: Institute for the Study of Labor.

BeCKer, Gary (1991). A Treatise on the Family. Cambridge, MA: Harvard University Press.

Bianchi, Suzanne. M.; Milkie, Melissa A.; Sayer, Liana C. and Robinson, John P. (2000). "Is Anyone Doing the Housework? Trends in the Gender Division of Household Labor". Social Forces, 79 (1), 191-228. $<$ https://doi.org/10.2307/2675569>

Bittman, Michael; England, Paula; Sayer, Liana; Folbre, Nancy and Matheson, George (2003). "When Does Gender Trump Money? Bargaining and Time in Household Work". American Journal of Sociology, 109 (1), 186-214. $<$ https://doi.org/10.1086/378341>

Blair, Sampson L. and Lichter, Daniel T. (1991). "Measuring the Division of Household Labor: Gender Segregation of Housework Among American Couples". Journal of Family Issues, 12 (1), 91-113. $<$ https://doi.org/10.1177/019251391012001007>

Blossfeld, Hans-Peter and Drobnic, Sonja (2001). "Careers of couples and trends in inequality". In: Blossfeld, Hans-Peter and Drobnic, Sonja (eds.). Careers of Couples in Contemporary Societies, 371-386. Oxford: Oxford University Press.

Blossfeld, Hans-Peter and Drobnic, Sonja (2001). Careers of Couples in Contemporary Societies. Oxford: Oxford University Press.

Boennke, Madeleine (2011). "Gender Role Attitudes around the Globe: Egalitarian vs. Traditional Views". Asian Journal of Social Science, 39 (1), 57-74.

<https://doi.org/10.1163/156853111x554438> 
Bolzendahl, Catherine I. and Myers, Daniel J. (2004). "Feminist Attitudes and Support for Gender Equality: Opinion Change in Women and Men, 1974-1998”. Social Forces, 83 (2), 759-789. <https://doi.org/10.1353/sof.2005.0005>

Bonke, Jens (2005). "Paid Work and Unpaid Work: Diary Information versus Questionnaire Information". Social Indicators Research, 70 (3), 349-368. <https://doi.org/10.1007/s11205-004-1547-6>

Brines, Julie (1994). "Economic Dependency, Gender, and the Division of Labor at Home". American Journal of Sociology, 100 (3), 652-688. <https://doi.org/10.1086/230577>

Carrasco, Cristina and Domínguez, Màrius (2015). "Measured Time, Perceived Time: A Gender Bias”. Time \& Society, 24 (3), 326-347. <https://doi.org/10.1177/0961463X14538917>

Carriero, Renzo and Todesco, Lorenzo (2018). "Housework Division and Gender Ideology: When Do Attitudes Really Matter?”. Demographic Research, 39 (39), 1039-1064. <https://doi.org/10.4054/DemRes.2018.39.39>

Castaño, Cecilia; Martín, Juan; Vázquez, Susana and Martínez, José-Luis (2010). "Female Executives and the Glass Ceiling in Spain". International Labour Review, 149 (3), 343-360. <https://doi.org/10.1111/j.1564-913X.2010.00090.x>

Coltrane, Scott (2000). "Research on Household Labor: Modeling and Measuring the Social Embeddedness of Routine Family Work". Journal of Marriage and Family, 62 (4), 1208-1233. $<$ https://doi.org/10.1111/j.1741-3737.2000.01208.x>

Cortina Trilla, Clara (2007). ¿Quién se empareja con quién? Mercados Matrimoniales y Afinidades Electivas en la Formación de la Pareja en España (Doctoral dissertation). Universitat Autònoma de Barcelona, Departament de Geografia.

Davis, Shannon N. and Greenstein, Theodore N. (2004). "Cross-National Variations in the Division of Household Labor". Journal of Marriage and Family, 66 (5), 1260-1271. <https://doi.org/10.1111/j.0022-2445.2004.00091.x>

Davis, Shannon N.; Greenstein, Theoodore N. and Gerteisen Marks, Jennifer P. (2007). "Effects of Union Type on Division of Household Labor: Do Cohabiting Men Really Perform More Housework?". Journal of Family Issues, 28 (9), 1246-1272. <https://doi.org/10.1177/0192513x07300968>

De Hauw, Yolien; Grow, André and Van Bavel, Jan (2017). "The Reversed Gender Gap in Education and Assortative Mating in Europe". European Journal of Population, 33 (4), 445-474. <https://doi.org/10.1007/s10680-016-9407-z>

Domínguez-Folgueras, Marta; Jurado-Guerrero, Teresa; Botía-Morillas, Carmen and Amigot-Leache, Patricia (2016). "'The House Belongs to Both': Undoing the Gendered”. Community, Work \& Family, 20 (4), 424-443. $<$ https://doi.org/10.1080/13668803.2016.1192525>

Esping-Andersen, Gøsta (1999). Social Foundations of Postindustrial Economies. Oxford: Oxford University Press.

- (2009). Incomplete Revolution: Adapting Welfare States to Women's New Roles. Cheshire: Polity. 
Esping-Andersen, Gøsta; Boertien, Diederik; Bonke, Jens and Gracia, Pablo (2013). "Couple Specialization in Multiple Equilibria". European Sociological Review, 29 (6), 1280-1294. <https://doi.org/10.1093/esr/jct004>

Esteve, Albert; García-Román, Joan and Permanyer, Iñaki (2012). "The Gender-Gap Reversal in Education and its Effect on Union Formation: The End of Hypergamy?". Population and Development Review, 38 (3), 535-546. <https://doi.org/10.1111/j.1728-4457.2012.00515.x>

Evertsson, Marie and Nermo, Magnus (2004). "Dependence within Families and the Division of Labor: Comparing Sweden and the United States". Journal of Marriage and Family, 66 (5), 1272-1286.

<https://doi.org/10.1111/j.0022-2445.2004.00092.x>

Fuwa, Makiko (2004). "Macro-Level Gender Inequality and the Division of Household Labor in 22 Countries". American Sociological Association, 69 (6), 751-767. <https://doi.org/10.1177/000312240406900601>

Gálvez, Lina and Rodríguez-Modroño, Paula (2016). "A Gender Analysis of the Great Recession and 'Austericide' in Spain”. Revista Critica de Ciências Sociais, 111, 133-152. <https://doi.org/10.4000/rccs.6492>

Geist, Claudia (2005). "The Welfare State and the Home: Regime Differences in the Domestic Division of Labour". European Sociological Review, 21 (1), 23-41. <https://doi.org/10.1093/esr/jci002>

Gimenez-Nadal, Jorge Ignacio; Molina, Jose Alberto and Ortega, Raquel (2012). "Self-Employed Mothers and the Work-Family Conflict". Applied Economics, 44 (17), 2133-2147. <https://doi.org/10.1080/00036846.2011.558486>

Gracia, Pablo and Kalmijn, Matthijs (2016). "Parents' Family Time and Work Schedules: The Split-Shift Schedule in Spain". Journal of Marriage and Family, 78 (2), 401-415. <https://doi.org/10.1111/jomf.12270>

Greenstein, Theodore N. (2000). "Economic Dependence, Gender, and the Division of Labor in the Home: A Replication and Extension". Journal of Marriage and Family, 62 (2), 322-335. <https://doi.org/10.1111/j.1741-3737.2000.00322.x>

- (1996). "Husbands' Participation in Domestic Labor: Interactive Effects of Wives' and Husbands' Gender Ideologies”. Journal of Marriage and the Family, 58 (3), 585-595. <https://doi.org/10.2307/353719>

Heisig, Jan Paul (2011). "Who Does More Housework: Rich or Poor?: A Comparison of 33 Countries". American Sociological Review, 76 (1), 74-99. <https://doi.org/10.1177/0003122410396194>

Hochschild, Arlie and Machung, Anne (1989). The Second Shift: Working Families and the Revolution at Home. New York: Viking.

Hwang, Jisoo (2016). "The Second Shift: Assimilation in Housework Time Among Immigrants". Review of Economics of the Household, 14 (4), 941-959. <https://doi.org/10.2139/ssrn.2371981>

Kamo, Yoshinori. (2000). “'He Said, She Said': Assessing Discrepancies in Husbands' and Wives' Reports on the Division of Household Labor". Social Science Research, 29 (4), 459-476. <https://doi.org/10.1006/ssre.2000.0674> 
Kan, Man Y. (2008). "Measuring Housework Participation: The Gap between 'Stylised' Questionnaire Estimates and Diary-based Estimate". Social Indicators Research, 86 (3), 381-400. <https://doi.org/10.1007/s11205-007-9184-5>

Klesment, Martin and Van Bavel, Jan (2017). "The Reversal of the Gender Gap in Education, Motherhood, and Women as Main Earners in Europe". European Sociological Review, 33 (3), 465-481. <https://doi.org/10.1093/esr/jcw063>

Konietzko, Thorsten (2015). "Self-Employed Individuals, Time Use, and Earnings". Journal of Family and Economic Issues, 36 (1), 64-83. <https://doi.org/10.1007/s10834-014-9411-6>

Kroska, Amy (2004). "Divisions of Domestic Work: Revising and Expanding the Theoretical Explanations”. Journal of Family Issues, 25 (7), 890-922. <https://doi.org/10.1177/0192513X04267149>

Molina, José Alberto; Campaña, Juan Carlos and Ortega, Raquel (2016). "What Do You Prefer for a Relaxing Time at Home: Reading, Watching TV or Listening to the Radio?". Applied Economics Letters, 23 (18), 1278-1284. $<$ https://doi.org/10.1080/13504851.2016.1150943>

Moreno-Colom, Sara; Ajenjo Cosp, Marc and Borràs Català, Vicent (2018). "La Masculinización del Tiempo Dedicado al Trabajo Doméstico Rutinario”. Revista Española de Investigaciones Sociológicas, 163, 41-58. <https://doi.org/10.5477/cis/reis.163.41>

Nordenmark, Mikael (2014). "Does Gender Ideology Explain Differences Between Countries Regarding the Involvement of Women and of Men in Paid and Unpaid Work?". International Journal of Social Welfare, 13 (3), 233-243. <https://doi.org/10.1111/j.1369-6866.2004.00317.x>

Parkman, Allen M. (2004). "Bargaining Over Housework: The Frustrating Situation of Secondary Wage Earners". The American Journal of Economics and Sociology, 63 (4), 765-794. <https://doi.org/10.1111/j.1536-7150.2004.00316.x>

Pittman, Joe F. and Blanchard, David (1996). "The Effects of Work History and Timing of Marriage on the Division of Household Labor: A Life-Course Perspective". Journal of Marriage and Family, 58 (1), 78-90. <https://doi.org/10.2307/353378>

Press, Julie E. and Townsley, Eleanor (1998). "Wive's and Husband's Housework Reporting: Gender, Class, and Social Desirability”. Gender \& Society, 12 (2), 188-218. <https://doi.org/10.1177/089124398012002005>

Presser, Harriet B. (1994). "Employment Schedules Among Dual-Earner Spouses and the Division of Household Labor by Gender". American Sociological Review, 59 (3), 348-364. $<$ https://doi.org/10.2307/2095938>

Sevilla-Sanz, Almudena; Gimenez-Nadal, Jose Ignacio and Fernández, Cristina (2010). "Gender Roles and the Division of Unpaid Work in Spanish Households". Feminist Economics, 16 (4), 137-184. <https://doi.org/10.1080/13545701.2010.531197>

Shelton, Beth Anne and John, Daphne (1996). "The Division of Household Labor". Annual Review of Sociology, 22 (1), 299-322. $<$ https://doi.org/10.1146/annurev.soc.22.1.299> 
Stier, Haya and Lewin-Epstein, Noah (2007). "Policy Effects on the Division of Housework". Journal of Comparative Policy Analysis: Research and Practice, 9 (3), 235-259. <https://doi.org/10.1080/13876980701494657>

Sullivan, Oriel (2011). "An End to Gender Display Through the Performance of Housework? A Review and Reassessment of the Quantitative Literature Using Insights from the Qualitative Literature". Journal of Family Theory \& Review, 3 (1), $1-13$. <https://doi.org/10.1111/j.1756-2589.2010.00074.x>

Treas, Judith and TaI, Tai (2016). "Gender Inequality in Housework Across 20 European Nations: Lessons from Gender Stratification Theories”. Sex Roles, 74 (11-12), 495-511. <https://doi.org/10.1007/s11199-015-0575-9>

Van Bavel, Jan and Klesment, Martin (2017). "Educational Pairings, Motherhood, and Women's Relative Earnings in Europe”. Demography, 54 (6), 2331-2349. <https://doi.org/10.1007/s13524-017-0621-z>

Van Bavel, Jan; Schwartz, Christine R. and Esteve, Albert (2018). "The Reversal of the Gender Gap in Education and Its Consequences for Family Life". Annual Review of Sociology, 44, 341-360. <https://doi.org/10.1146/annurev-soc-073117-041215>

Van Berkel, Michael and De Graaf, Nan Dirk (1999). "By Virtue of Pleasantness? Housework and the Effects of Education Revisited”. Sociology, 33 (4), 785-808. <https://doi.org/10.1017/s0038038599000498>

West, Candance and Zimmerman, Don H. (1987). “Doing Gender”. Gender \& Society, 1 (2), 125-151.

<https://doi.org/10.1177/0891243287001002002> 